\title{
Lower Eocene sedimentary succession and microfossil biostratigraphy in the central northern Caucasus basin
}

\author{
E. Shcherbinina A. lakovleva Yu. Gavrilov O. Golovanova N. Muzylöv
}

\author{
Geological Institute of the Russian Academy of Sciences \\ Pyzhevsky 7, Moscow 119017, Russia. Shcherbinina \\ E-mail: katuniash@gmail.com
}

A B S TR A C T

The lower Eocene sediments from the classical Paleogene section exposed along the Kheu River, northern Caucasus, southern Russia are here studied. This $c a$. 50m thick succession is lithologically contrasting: the lower and upper parts are composed by soft marls separated by a thick Radiolaria-rich unit of non-calcareous and low-calcareous mudstones with intercalations of compact cherty layers. According to nannofossil and dinocyst biostratigraphy, the unique intercalation of Total Organic Carbon (TOC)-rich sediment (sapropelitic bed) in the lower part of the lower Eocene correspond to the Paleocene-Eocene Thermal Maximum (PETM) and a series of sapropelitic interlayers in the upper marly part of the lower Eocene succession correlates with the Early Eocene Climatic Optimum (EECO). The study of nannofossil and dinocyst assemblages enabled detailed zonal subdivision and first-order calibration of nannofossil and dinocyst bio-events during this time-span. The studied interval of the section embraces the complete succession of nannofossil zones NP9-NP13 of Martini, 1971, CP8-CP11 of Okada and Bukry, 1980 and CNP11-CNE5 of Agnini et al., 2014. By means of dinocyst stratigraphy, the succession of Apectodinium hyperacanthum, Axiodinium augustum, Deflandrea oebisfeldensis, Dracodinium astra, Stenodinium meckelfeldense, Dracodinium varielongitudum, Ochetodinium romanum/Samlandia chlamydophora and Areosphaeridium diktyoplokum zones are identified in the Ypresian part of the Kheu section.

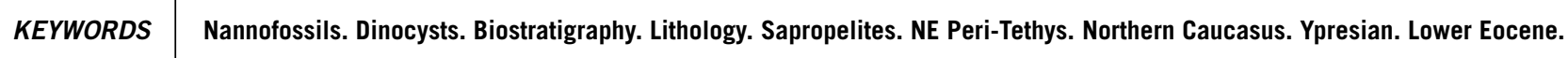

\section{INTRODUCTION}

In the early Eocene, the huge basin of the NE Peri-Tethys was widely connected with the Tethyan realm by a system of the gateways and had restricted connection with the Boreal realm via the shallow Turgay Strait (Fig. 1A). The central Caucasus basin was the deepest part of this marine region with mostly calcareous and siliciclastic-calcareous sedimentation. The most continuous Paleogene succession is exposed $15 \mathrm{~km}$ southeastward from the city of Nalchik, along the middle reaches of the Kheu River, KabardinoBalkaria, central northern Caucasus (Fig. 1B). This classical perfectly exposed section lacking recognizable hiatuses and containing diverse microfossils (planktonic and benthic foraminifera, nannofossils, dinocysts) became a subject of detailed stratigraphic research since the $40 \mathrm{~s}$ of the last century. The most of the works were focused on the biostratigraphical subdivision of the Paleogene sediments of the Kheu section based on regional planktonic foraminiferal zonation (e.g. Beniamovsky, 2001; Bugrova et al., 1988; Leonov and Alimarina, 1964; Shutskaya, 1960; Subbotina, 1947, and others). Later, the foraminiferal zones were correlated with the nannofossil zones (Krasheninnikov and Muzylöv, 1975) and some intervals of this section were studied again in better detail (Beniamovski et al., 2003; Beniamovskiy, 2011; Shcherbinina et al., 2016). By now,

(C) E. Shcherbinina, A., lakovleva, Yu., Gavrilov, O., Golovanova, N., Muzlöv, 2020 CC BY-SA 
dinocysts have only been studied in some specific intervals of the Kheu section: the uppermost Thanetian (Radionova et al., 2009), Paleocene-Eocene Thermal Maximum (PETM) (Shcherbinina et al., 2016) and the middle Eocene (Iakovleva et al., in press; Zaporozhets, 2001).

The Paleocene-Eocene sediments of the Kheu section host a complete record of the global and regional paleoecological events (Muzylöv, 1994). They include intervals rich in organic matter which represent the sedimentary response to the early Eocene climatic perturbations. The lower Eocene (Ypresian) interval of the Kheu section encompasses the uppermost Nalchik, Abaza and Cherkessk formations. Selandian to lowermost Ypresian greenish marly sediments (named Nalchik Formation (Fm.) in the studied area), cover a large area from Crimea to eastern Caucasus. The intercalation of the sapropelitic bed in the uppermost part of this formation corresponds to PETM (Gavrilov et al., 2000; Gavrilov et al., 2003; Shcherbinina et al., 2016). The geographic range of the lower Ypresian siliciclastic Abaza Fm. is restricted to the small area of the central northern Caucasus between Kuban and Cherek Rivers having the maximum thickness (ca. 20m) in the Kheu section. In the most complete successions of the deepest part of the Peri-Tethyan Basin, the upper Ypresian interval (NP12 to lower part NP13 nannofossil zones) contains intercalations of sediments rich in organic matter in varying extents, which likely display the regional response to the Early Eocene Climatic Optimum (EECO), encompassing this time span. The upper Ypresian marly Cherkessk Fm. exposed along the Kheu R. contains the highest number of sapropelitic intercalations forming a cyclically built succession.

Our recent study of the lowermost Eocene interval of the Kheu section revealed the specificities and dynamics of the PETM in the deepest part of the NE Peri-Tethys (Shcherbinina et al., 2016). Here we present a highresolution lithostratigraphy and nannofossil and dinocyst biostratigraphy of the upper part of the lower Eocene succession. With this results we aim to build the basis for forthcoming paleoecological reconstructions of the Caucasian Basin during the early Eocene.

\section{MATERIAL AND METHODS}

The lower Eocene succession is exposed along the Kheu R. stream crossing the village of Gerpegezh $\left(43^{\circ} 22^{\prime} 22.0^{\prime \prime} \mathrm{N}\right.$ 4339'04.2'E, see Fig. 1C). This part of the section was revisited during several field trips and the total of 105 samples were collected from the $c a$. $47 \mathrm{~m}$ thick succession with resolution from few centimeters within sapropelitic beds in the upper part of the studied section (Cherkessk Fm.) to $1 \mathrm{~m}$ in the low-calcareous Abaza Fm.

The nannofossils were examined from the smear-slides made of raw sediments of all samples collected using standard technics described in Bown and Young, 1998. The study of smear-slides and nannofossil pictures were made using the light microscope Olympus BX41 (x1200) and video-camera Infinity $\mathrm{X}$. The semi-quantitative estimation
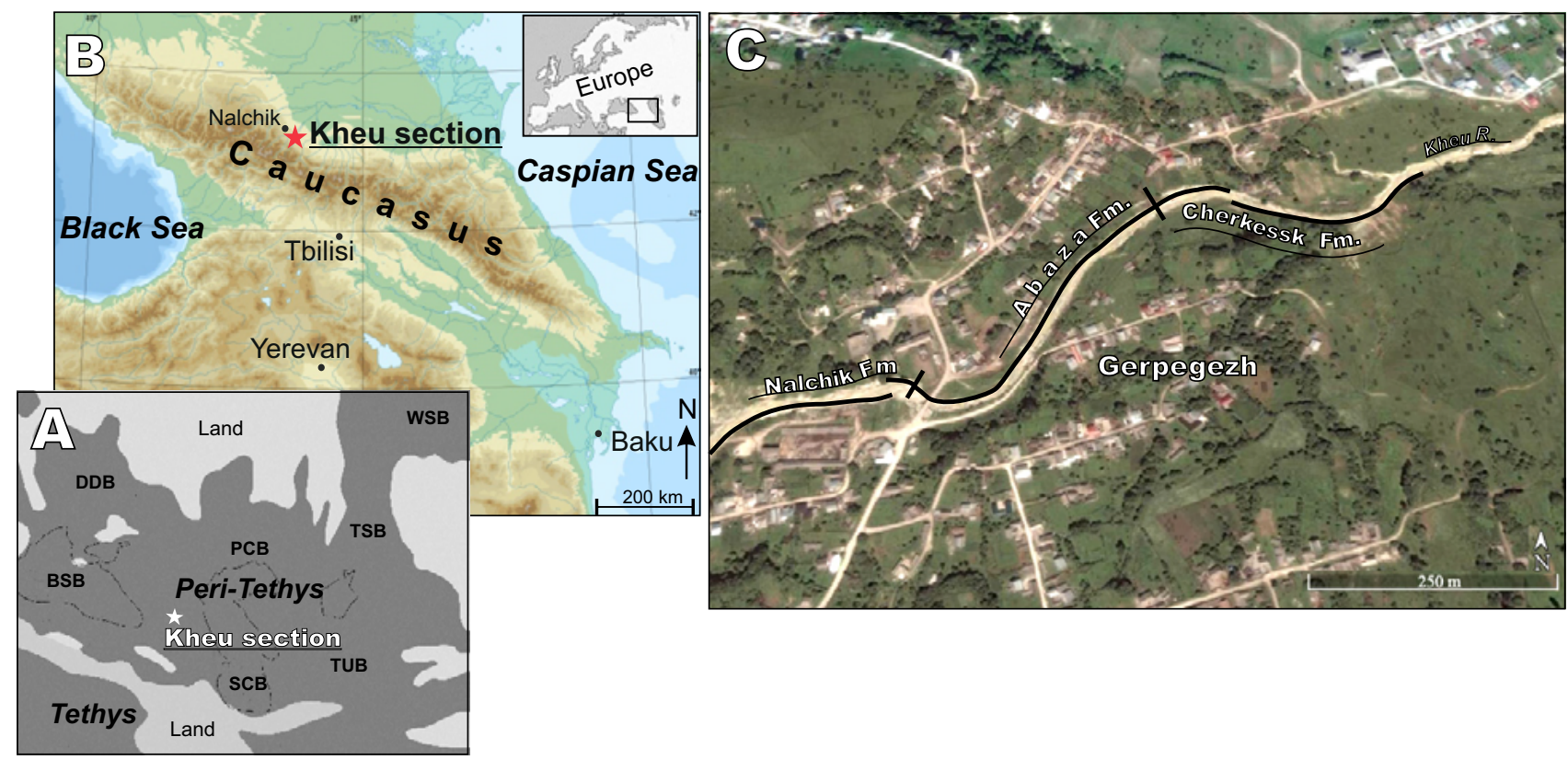

FIGURE 1. The location of Kheu section in the A) paleo- and B) modern geography; C) outcrops of the Paleocene and lower Eocene formations along the Kheu R. in the territory of the village of Gerpegezh. BSB: Black Sea Basin; DDB: Dnieper-Donetz Basin; PCB: Peri-Caspian Basin; SCB: Scythian Basin; TSB: Turgay Strait Basin; TUB: Turan Basin. 
of the abundances of individual species is made with following gradations: a: abundant $(>5$ specimens per field of view (f.v.) of the microscope), c: common (1-5 specimens per f.v.), r: rare (one specimen per 2-10 f.v.), f: few (one specimen per more than 10 f.v.).

Palynomorphs were concentrated according to the standard palynological techniques of the Russian Academy of Sciences. Samples were i) processed with $10 \%$ hydrochloric acid until the calcium carbonate was dissolved; ii) processed with $10 \%$ tetrasodium pyrophosphate $\left(\mathrm{Na}_{4} \mathrm{P} 2 \mathrm{O} 7 \times 10 \mathrm{H}_{2} \mathrm{O}\right)$ to disperse the clay; iii) washed several times to eliminate clayey compounds; iv) centrifuged with a heavy liquid $\left(\mathrm{K}_{2} \mathrm{CdJ}_{4}\right)$ with a specific gravity of $\left.2.25 ; \mathrm{v}\right)$ washed in water and then treated with $10 \%$ hydrofluoric acid until the siliceous matter was dissolved and vi) boiled with $10 \%$ hydrochloric acid to remove fluoro-silicate compounds. The material was not sieved. The residues were mounted on glass slides using glycerine jelly. A minimum of 200 palynomorphs were counted and grouped into 10 broad categories (dinocysts, acritarchs, prasinophytes, green algae, fungi, angiosperms, conifer bisaccate pollen, spores and unknown palynomorphs). Next, a minimum of 200 dinocysts (if possible) were counted. The remaining material was scanned for rare dinocyst taxa. Dinoflagellate cyst taxonomy follows Williams et al. (2017).

The calcium carbonate composition was determined using X-ray diffractometry. Chemical analysis of $\mathrm{CaCO}_{3}$ was made using a gravimetric technique; its content was calculated after the treatment of sediments with $\mathrm{HCl}$ and $\mathrm{CO}_{2}$ absorption in Ascarite. Total Organic Carbon (TOC) was analyzed gravimetrically after oxidation of organic matter with chromium trioxide.

\section{RESULTS}

\section{Lithology and sedimentation}

In the Kheu section, the base of the Ypresian corresponds to the SaproPelitic Bed (SPB), representing the regional expression of the global event of the PETM (Gavrilov et al., 2003, 2009; Shcherbinina et al., 2016). The accumulation of the dark thinly laminated low-calcareous SPB was preceded by the large scale regression forming the erosional surface and stratigraphic hiatus in the shallower areas of the NE Peri-Tethys (Gavrilov et al., 2003), which mark the Sequence Boundary (SB1, Fig. 2). The event of PETM significantly affected the $\mathrm{CaCO}_{3}$ accumulation. The cyclicity of calcium carbonate accumulation within SPB and the impact of calcareous microbiota are discussed in Shcherbinina et al., 2016. Although the $\mathrm{CaCO}_{3}$ concentrations are similar below and above the SPB (Fig. 3 ), it has different composition in these intervals. Below the
SPB, calcium carbonate is mainly composed of calcareous nannofossils and weathered and redeposited carbonate in form of pelitic particles (micarb). Above the SPB, the $\mathrm{CaCO}_{3}$ content became partially restored (up to 23\%) in the $2 \mathrm{~m}$ thick topmost part of the Nalchik Fm. (see Fig. 3) due to the restoration of nannofossil abundance, but micarb is almost absent from this sediment. The occurrence of glauconite and coarser siliciclastic component in this part of formation likely indicates regressive trend. The transition from bluish-greenish-gray calcareous sediments of Nalchik Fm. to khaki-colored Abaza Fm. is characterized by decline of calcareous microbiota and occurrence of phosphatic nodules and individual siliceous concretions (Fig. 4A). This transition corresponds to the switch from mainly calcareous to siliceous sedimentation that persisted for ca. 2.5 Ma in this part of the Caucasian basin.

The Abaza Fm. is composed by ca. $20 \mathrm{~m}$ thick succession of dark non-laminated greenish-gray mudstone lacking organic matter and containing $10-30 \mathrm{~cm}$ thick intercalations of more compact cherty layers. $\mathrm{CaCO}_{3}$ content varies from 0 to $4 \%$ in the lower part of the formation and progressively increases up to $20 \%$ toward its top due to gradual restoration of calcareous microfossils, which form the main calcareous component in these sediments. Radiolarians and diatoms (Fig. 4B) are important component of microbiota assemblage in the sediments of Abaza Fm. (Agarkov et al., 1989; Radionova and Khokhlova, 1994) and they are suggested to be the main silica suppliers for the formation of cherty intercalations concurrently with enhanced supply of dissolved silica from the neighboring land. The sediments of Abaza Fm. are extensively borrowed that testifies normal oxic bottom conditions and, thus, oxygen exchange in the water column. The progressive restoration of calcareous microbiota in the upper Abaza Fm. (Fig. 4C) evidences the slow deepening of the basin during its accumulation, although the occurrence of glauconite and particles of terrestrial organic matter indicate still shallow environment.

The Abaza and Cherkessk fms. have gradational contact characterized by gradual increase of calcium carbonate value and total abundance of calcareous microfossils. The few $\mathrm{cm}$ thick layer enriched in clayey and sandy material found within the interval of NP10d Subzone (see below) corresponds to the regional hiatus in the uppermost part of the NP10 or CP9a nannofossil Zone/Subzone (base of Cherkessk Fm.), documented in many areas of the Former USSR from Crimea to Central Asia (Muzylöv, 1980). This hiatus marks the sequence boundary SB2, followed by new deepening of the basin and return to mostly calcareous sedimentation.

The Cherkessk Fm. is characterized by generally high $\mathrm{CaCO}_{3}$ content, which dramatically drops at the few specific 


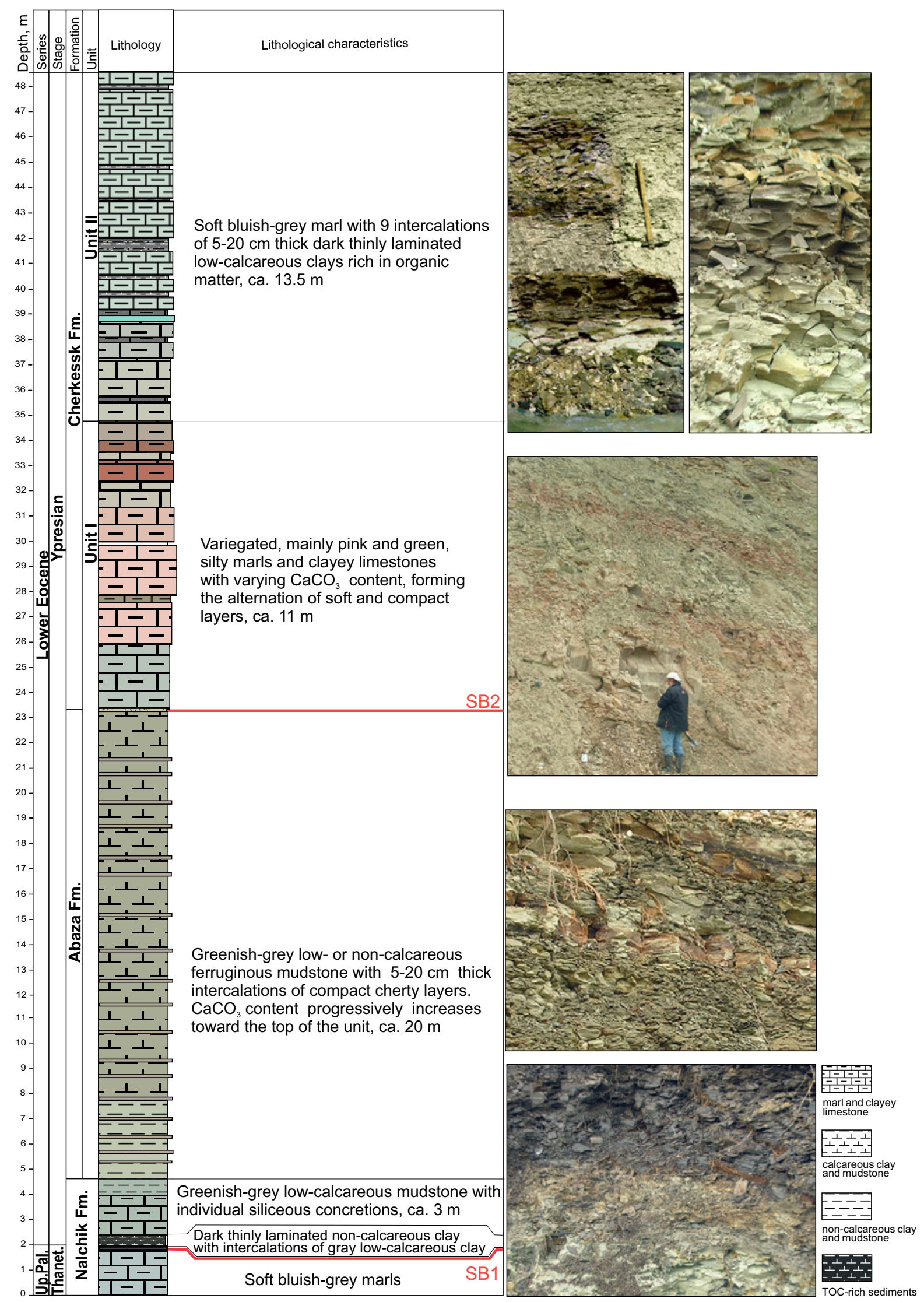

FIGURE 2. Lithostratigraphic division of the lower Eocene sediments of the Kheu section. 


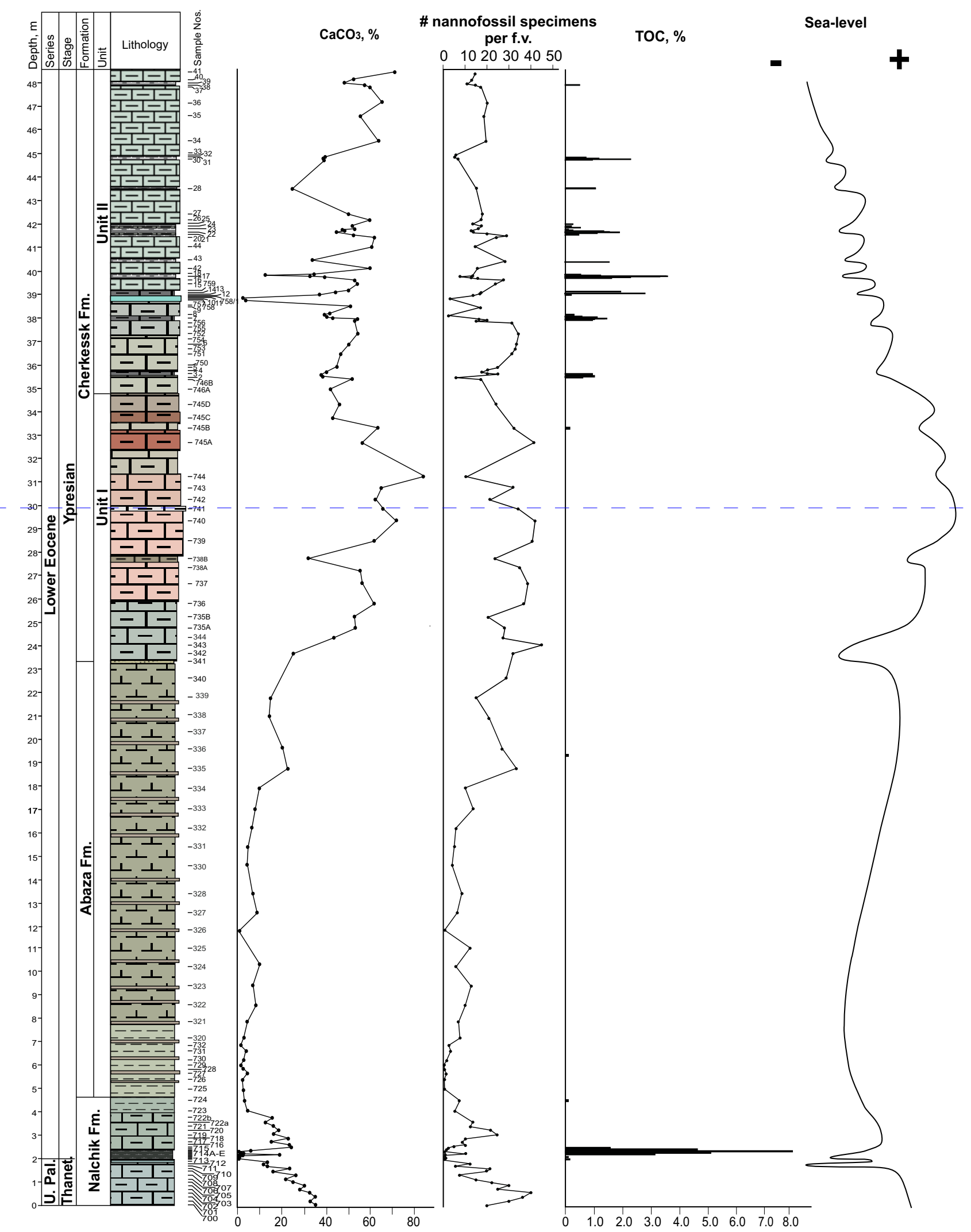

FIGURE 3. Calcium carbonate content, average number of nannofossil specimens per field of view (f.v.) of the microscope, TOC content and trends in the sea-level changes in the lower Eocene sediments of the Kheu section. For legend, see Figure 2. 
levels, and large variations in the rock color. Foraminifera became important supplier of calcium carbonate into sediments. Two clearly distinguished units can be recognized within the Cherkessk Fm. The Unit 1 (ca. $11.5 \mathrm{~m}$ thick, see Fig. 2) is composed by alternation of the variegated (pink, light grey, yellowish and white) marls and clayey limestones, forming the cliff on the left bank of the Kheu R. This Unit is characterized by the highest $\mathrm{CaCO}_{3}$ content of the studied interval. The sources of calcium carbonate in the sediments of Cherkessk Fm. are calcareous microorganisms (foraminifera and/or nannofossils) and micarb. However, the proportion in the abundance of these $\mathrm{CaCO}_{3}$ providers varies in the different intervals of the Unit 1. For example, the high $\mathrm{CaCO}_{3}$ content at the level $23 \mathrm{~m}$ (sample 741) is more likely caused by multiple sources: common calcareous nannofossils (high abundance per microscope field of view, see Fig. 3), foraminifera and occurrence of relatively high amount of micarb (Fig. 4C). The calcium carbonate content (68\%), nannofossil abundance (see Fig. 3) are still high at the level $24.4 \mathrm{~m}$ (sample 743), but foraminifera are hardly visible in the thin-section (Fig. 4D), suggesting that nannofossils are the main constituting element of $\mathrm{CaCO}_{3}$ in this interval.
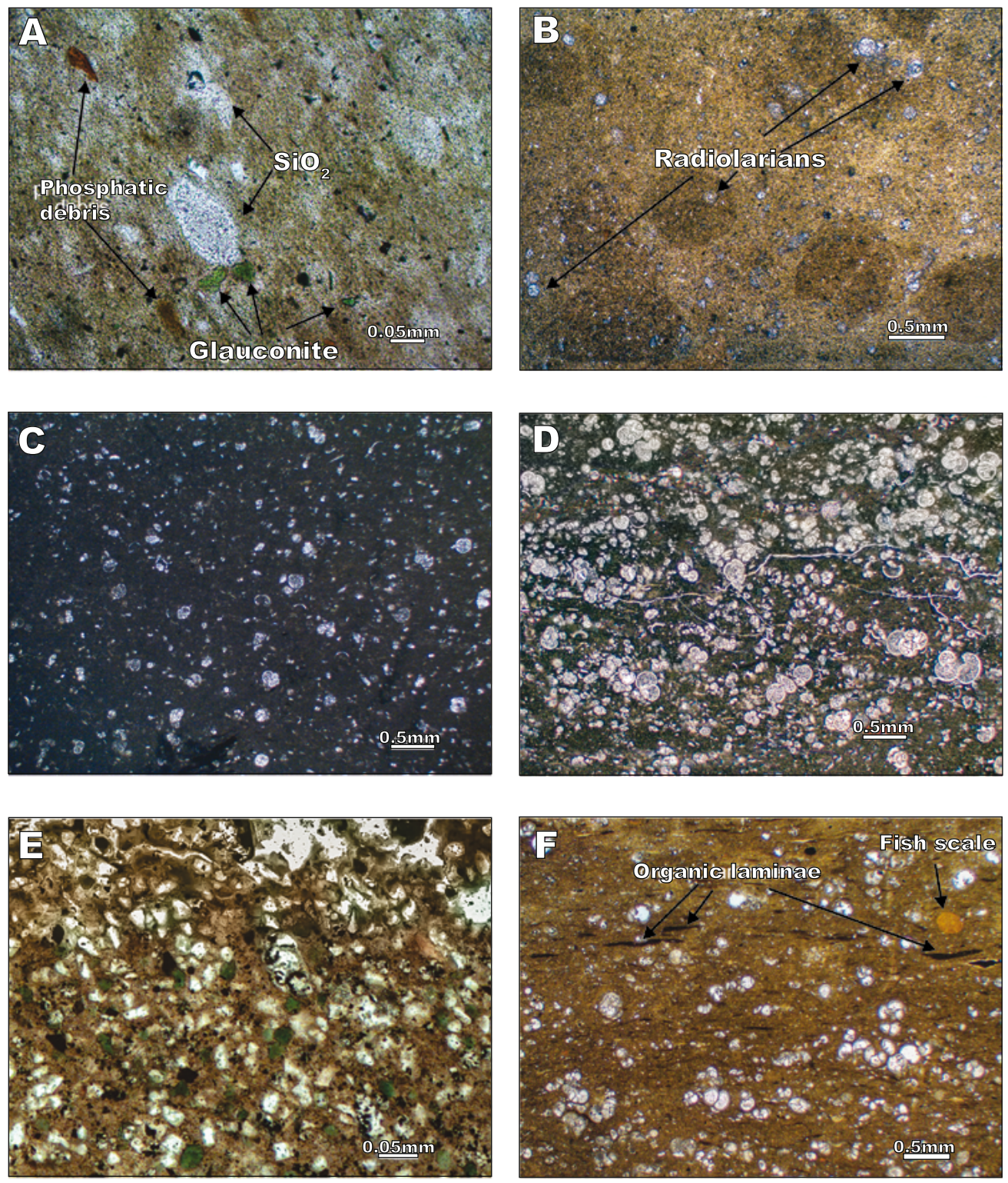

FIGURE 4. Thin-sections of the lower Eocene sediments from Kheu section. The length of magnification bar: A, E= $0.05 \mathrm{~mm} ; \mathrm{B}, \mathrm{C}, \mathrm{D}, \mathrm{F}=0.5 \mathrm{~mm}$. A: greenish-gray mudstone with glauconite and phosphatic debris, sample 727, base of Abaza Fm.; B: non-calcareous bioturbated mudstone with radiolarians, sample 730, lower part of Abaza Fm.; C: calcareous mudstone with foraminiferal shells, sample 335, upper part of Abaza Fm., cross-polarized light; D: foraminiferal marl, sample 741, Unit I, Cherkessk Fm.; E: underlying the sapropelitic intercalation marl rich in micarb and glauconite, sample 6, Unit II, Cherkessk Fm.; F: sapropelitic layer with alternation of foraminifera bearing and non-calcareous microlayers, sample 7, Unit II, Cherkessk Fm.. 
Radiolarians persist to be present in the Cherkessk Fm., but show much lower abundance and had minor impact into the sediment composition. Few meters above, foraminifera recover their abundance, forming clayey foraminiferal limestone at the level $31.5 \mathrm{~m}$ (sample 744) while nannofossils become less abundant (see Fig. 3).

The Unit 2 (ca. $13.5 \mathrm{~m}$ thick) is composed of soft bluish-gray coarsely bioturbated marl with $7-30 \mathrm{~cm}$ thick intercalations of dark thinly laminated TOC-rich calcareous clays. $\mathrm{CaCO}_{3}$ content varies from 55 to $70 \%$ in the embedding marls and significantly drops (up to $15 \%$ ) in the TOC-rich sediments (see Fig. 3). The dark intercalations are SPBs with various TOC concentrations (from 0.7 to $3.8 \%$ ), containing small pyrite concretions, tiny wood debris, fish scales and shark teeth (Fig. 4F). The SPBs of Unit II have very distinct bottom and gradational contacts with embedding sediments at their top, showing progressive decrease in TOC content. The SPBs contain fine borrowing at the base, which become coarser to their tops, which evidences mostly normal oxic conditions during their accumulation. Clay mineral composition is similar in the SPBs and underlying and overlying sediments: the main clay composing mineral are mixed-layered smectite and hydromica, kaolinite and chlorite are present in minor values (Gavrilov and Muzylev, 1991). The recent analytical study (Gavrilov and Muzylev, 1991) revealed their enrichment in many trace elements ( $\mathrm{S}, \mathrm{Co}, \mathrm{P}, \mathrm{Ni}, \mathrm{V}, \mathrm{Mo}, \mathrm{Cu}, \mathrm{Cr}$, among others), while the concentrations of $\mathrm{Mn}$ and Ti dramatically drops comparing to surrounding sediments.

The rhythmical intercalation of SPBs represents, more likely, the climatic response to Milankovich orbital cycles. At the same time, the TOC is spread unevenly in the light marls of Unit II: the thicker SPBs $(20-25 \mathrm{~cm})$ with higher TOC concentrations occur close to the middle part of the Unit (see Figs. 2;3), where they are separated by thin marly intervals $(30-50 \mathrm{~cm})$. In the lower and upper parts of the Unit II, the SPBs occur in thicker intervals (up to few meters); they are thinner $(5-15 \mathrm{~cm})$ and enriched in TOC in a minor extent being compared with the middle part of the Unit. These likely indicate the progressive onset and termination of environmental instability in the basin of northern Caucasus.

The increase of coarser clastics and glauconite toward the top of the Unit II and reduce in calcareous microplankton total abundance, possibly, indicate the beginning of the progressive the shallowing of the basin culminated at the Ypresian/Lutetian transition.

\section{Calcareous nannofossils}

The high-resolution study of nannofossil stratigraphic distribution in the Kheu section shows the large variations in total nannofossil abundance and species diversity in the early Eocene sediments. The dramatic decline of nannofossils and reorganization of nannofossil assemblage during the PETM corresponding to the SPB (Shcherbinina et al., 2016) were followed by short-time recovery of total abundance in the topmost Nalchik Fm., where the last Paleocene taxa (Fasciculithus, Neochiastozygus, Heliolithus, among other) became extinct. Few meters above, at the Nalchik/Abaza Fm. transition, the nannofossil assemblage underwent a new phase of reduced abundance due to facies changes.

Nannofossils are absent from the lowermost part of the Abaza Fm. (5.0-7.8m, samples 724-732) and their occurrence remain scarce to rare in the rest of the Formation, progressively increasing their total abundance and species diversity toward the top of Formation, where they appear to be the main producers of the $\mathrm{CaCO}_{3}$. This low-diversity assemblage is characterized by small size of all coccoliths and wide domination of Toweius and Coccolithus (Appendix, Fig. I; II). The small-size Toweius (mainly $T$. pertusus) dominate over Coccolithus in the lower part of the formation; the consistent medium-size T. callosus appear in its upper part keeping this ratio in spite of increasing Coccolithu abundance. The warm-water Discoaster and Sphenolithus (mainly S. moriformis) are rare throughout Abaza Fm., but increase their abundance toward the upper part of the Formation. Only few coolwater Chiasmolithus were found in the interval of Abaza Fm.

The low-diversity assemblage of the lowermost part of Abaza Fm. (see Appendix, Table I), lack both in the Paleocene and characteristic Eocene species, corresponds to NP9 zone of Martini (1971). It occurs above the markers of NP9c subzone of Aubry and Salem (2012) and CP8b subzone of Okada and Bukry (1980), the Lowest Occurrences (LOs) of Discoaster mahmoudii and Campylosphaera eodela, respectively and the Highest Occurrence (HO) of Fasciculithus tympaniformis, which also corresponds to the base of CNE2 zone of Agnini et al. (2014) (Fig. 5).

The early diversification of nannofossils after PETM decline in the Kheu section (Shcherbinina et al., 2016) is related to Coccolithus and Tribrachiatus radiations. Besides, the large occurrence of the first Cenozoic rhabdoliths Blackites solus and appearance of first representatives of pontosphaerids and helicosphaerids is the peculiarity of nannofossil assemblage from the upper part of the Abaza Fm. The LOs of $C$. foraminis and $C$. latus occur prior to the LO of $T$. bramlettei corresponding to the base of NP10 (sample 323), but they are very scarce in the early Ypresian sediments. The LO of Discoaster diastypus in the sample 327 marks the base of CP9 
zone. The NP10b subzone corresponds to the range of Tribrachiatus digitalis, which occurs between samples 328 and 331. After a slight recovery of the nannofossil abundance and species diversity roughly corresponding to the interval of NP10a subzone, the assemblage of the NP10b subzone becomes scarce again and only very few specimens of the marker species were found. This causes lesser precision of its stratigraphic range in the Kheu section and lesser accuracy of the NP10b subzone boundaries. The interval between the $\mathrm{HO}$ of $T$. digitalis and LO of $T$. contortus (sample 340) is identified as the NP10c subzone. It is characterized by farther increase of nannofossil species diversity and wide occurrence of small Toweius. The Abaza and Cherkessk fms. boundary falls into the middle of NP10d subzone and, possibly, corresponds to the short hiatus marked by thin sandy layer. The sedimentary hiatus, if any, cannot be detected biostratigraphically in the Kheu section. However, it could cause the small thickness of the sediments corresponding to NP10d subzone. The LO of $T$. orthostylus in the NP10d subzone defines the base of CNE3 zone of Agnini et al., 2014 in the sample 343. Common occurrence of Blackites solus and abundant Zygrhablithus bijugatus are featured for the base of Cherkessk Fm.

The nannofossil assemblage of the Unit I of Cherkessk Fm. is characterized by highest for total abundance and high diversification rate. The LO of $T$. contortus in the lowermost part of Cherkessk Fm. defines the bottoms of both NP11 zone and CP9b subzone. Nannofossil species diversity increases significantly in this interval: typical short-lived Ypresian species Girgisia gammation and Toweius magnicrassus and long-lived Eocene Helicosphaera seminulum appear. Sphenolithus-lineage underwent rapid radiation showing the LOs of $S$. radians, $S$. editus, S. arthurii and $S$. orphanknollensis in the lowermost Cherkessk Fm. Pontosphaera and Blackites also became more common and diverse.

The LO of Discoaster lodoensis in the sample 740 is the important marker for all three nannofossil zonations defining the bases of NP12, CP10 and CNE4 zones. The interval above this biohorizon is characterized by successive extinctions of the Paleocene survivors Ellipsolithus macellus, Chiasmolithus bidens, Discoaster salisburgensis, etc. The LO of Coccolithus crassus in the sample 745D marks the base of CP11 zone close to the base of the Unit II. Zygrhablithus bijugatus and Toweius callosus, very abundant in the underlying sediments, reduce their abundance dramatically, while Coccolithus spp. increases it.

The peculiarity of nannofossil assemblage of the lower Unit II is the consistent occurrence of Scyphosphaera, holococcoliths and micrantoliths. The important upper
Paleogene taxa Reticulofenestra and Cyclicargolithus appear in this interval, and the nannofossils assemblage displays its highest species diversity of the studied interval. Nannofossil total abundance significantly drops in the sapropelitic beds, but many LOs are found in these layers. Blackites solus, forming the markable component of earlier nannofossil assemblage, disappears in this interval. The HO of Tribrachiatus orthostylus in the middle of Unit II (sample 20) defines the bases of NP13 and CNE5 zones. Above this level, nannofossils decrease their total abundance and species diversity. Toweius spp. exhibits farther decline: small-sized taxon (T. pertusus) gradually decreases its abundance, medium-sized $T$. callosus becomes eliminated, and only large-sized T. magnictassus remains to be constantly present. Generally, the high rate of nannofossil diversification, occurrence of short-lived species (Blackites truncatus, Lophodolithus reniformis, Scyphosphaera tubicena, Nannoturba jolotteana, among others) and the large variations in total nannofossil abundance likely suggest the high environmental dynamics during the time span of Cherkessk Fm.

\section{Palynology}

In the scope of the present study, 96 samples from the lower Eocene part of the Kheu section have been analysed palynologically. In general, the most part of the samples revelead quantitatively representative assemblages of dinocysts and other palynomorphs. Dinocysts mostly dominate the assemblage, especially in the lower Abaza Fm. The sapropelitic beds of the Cherkessk Fm. are characterised by higher abundance of acritarchs and angiosperms pollen grains. Additionally, the Cherkessk Fm. is marked by significant fluctuations in the ratio of gonyaulacoidean and peridinioidean dinocysts. Stratigraphic distribution of dinocyst taxa is done on Tables II and III. The most characteristic dinoflagellate cyst species are illustrated on Figures III-VI.

According to our previously published results (Shcherbinina et al., 2016), the lowermost part of the SPB, corresponding to the onset of the Carbon Isotope Excursion (CIE) associated with the PETM, is marked by the LOs of species Axiodinium augustum, Epelidinium brinkhuisii and Epelidinium pechoricum (sample 714A). The $\mathrm{HO}$ of Axiodinium augustum is recognised in the sample 721 $(\sim 1.75 \mathrm{~m}$ above the SPB and slightly after the end of the CIE). Consequently, the part of the Nalchik Fm. between samples $714 \mathrm{~A}$ and 721 corresponds to the interval of the Axiodinium (=Apectodinium) augustum Zone, known from different Eurasian dinocyst zonations (Iakovleva and Aleksandrova, 2013; Iakovleva, 2017; Heilmann-Clausen, 1994; Mudge and Bujak, 1994; Powell, 1992) and associated with the PETM event worldwide (Crouch et al., 2001). The LOs of Ax. augustum, Ep. brinkhuisii and Ep. pechoricum 


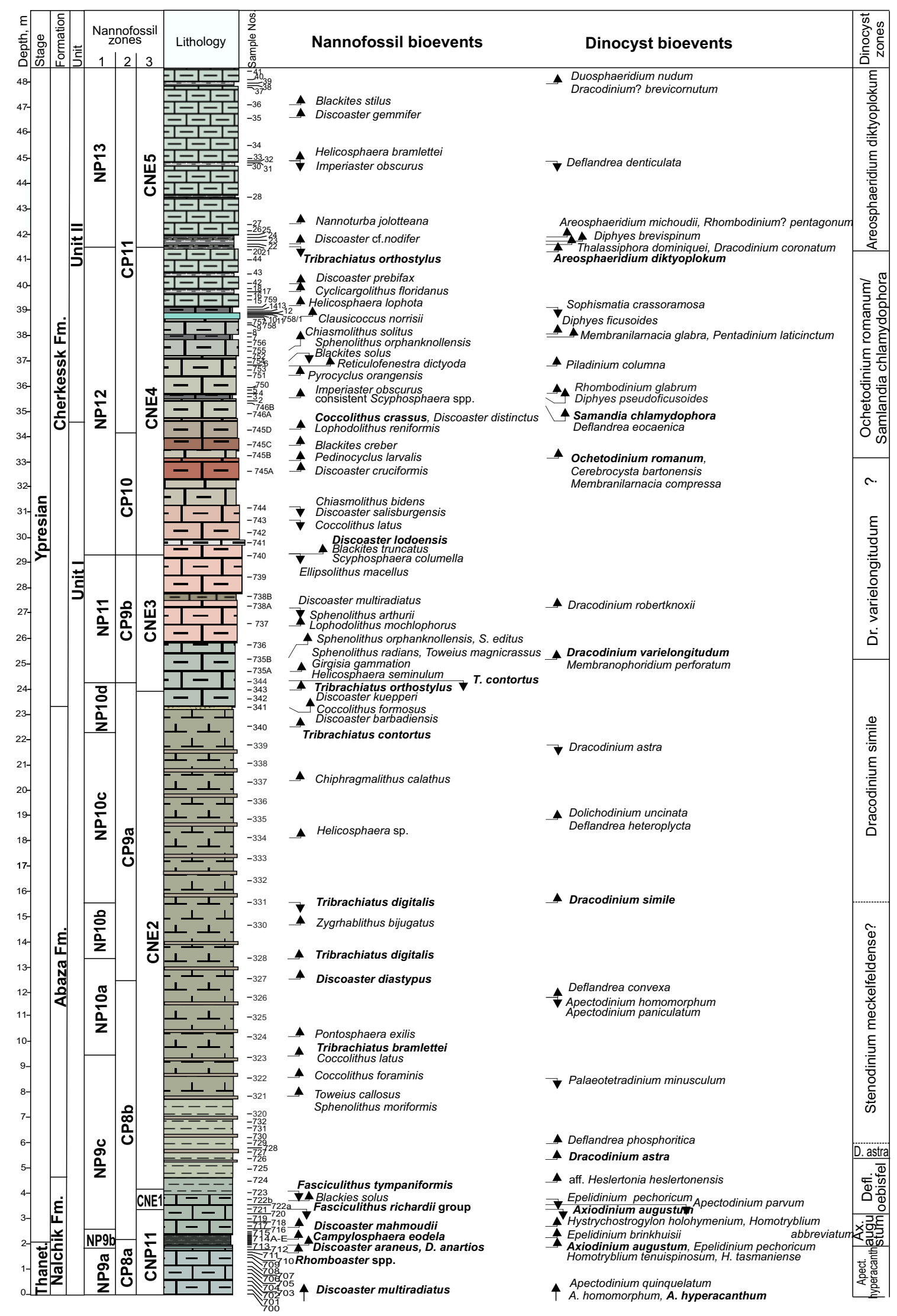

FIGURE 5. Biostratigraphic summary of Kheu section: nannofossil and dinocyst zonal division and correlation of bioevents. For legend, see Figure 2. 
are observed within the SPB between the LO of nannofossil Rhomboaster spp. and the LOs of Campylosphaera eodela and Discoaster araneus. Besides, the LOs of Homotryblium tasmaniense, $H$. tenuispinosum and Muratodinium fimbriatum are recognized within the SPB. The successive LOs of Homotryblium abbreviatum, Hystrichostrogylon holohymenium and Biconidinium longissimum, in their turn, are revealed above the SPB and the LO of Discoaster mahmoudii nannofossil. Finally, the HO of Axiodinium augustum (sample 721, 1.75m above the SPB) coincides with the $\mathrm{HO}$ of Fasciculithus richardii group. The uppermost part of the Nalchik Fm. (samples 722-725) is characterized by the disappearance of the most Apectodinium spp. and the $\mathrm{HO}$ of Epelidinium pechoricum (sample 723) close to the HO of nannofossil Fasciculithus tympaniformis. At the same time, the dinocyst assemblage does not contain the younger key-species Dracodinium astra, while the abrupt influx of the Areoligera eco-group is observed at the base of this interval that indicates the Deflandrea oebisfeldensis Zone, which was identified in the eastern Peri-Tethys (Iakovleva, 2017) and well known in the NW European basins (Powell, 1992; as Viborg-7 Zone in Denmark, Heilmann-Clausen, 1985; as E1b-c Subzone in the North Sea, Mudge and Bujak, 1996; as Glaphyrocysta ordinata Zone in southern England, Powell et al., 1996) and Western Siberia (Iakovleva and Aleksandrova, 2013).

The stratigraphically important species Dracodinium astra has its LO at the base of the Abaza Fm. (sample 726, NP9c Zone), indicating the interval of cognominal dinocyst Zone of the eastern Peri-Tethys (Iakovleva, 2017), Western Siberia (Iakovleva and Aleksandrova, 2013) and NW Europe (=Wetzeliella astra Zone, Powell, 1992) within the lowermost Abaza Fm. (samples 726-728).

The LO of Deflandrea phosphoritica is recognized in the sample $729, \sim 3.5 \mathrm{~m}$ below the LO of nannofossil Tribrachiatus bramlettei. Unfortunately, the relatively poor dinocyst assemblage of the lower Abaza Fm. mudstone did not reveal the stratigraphically important species Stenodinium meckelfeldense and Axiodinium lunare. Nevertheless, based on the records of Deflandrea phosphoritica from the base of the Stenodinium (=Wetzeliella) meckelfeldense Zone in the eastern Peri-Tethys (Iakovleva, 2017), Western Siberia (Iakovleva and Aleksandrova, 2013), North Sea (E2a subzone, Mudge and Bujak, 1994) and NW Europe (Powell, 1992), we suggest that the lower Abaza Fm. (samples 729330) possibly corresponds to the interval of Stenodinium meckelfeldense Zone. The $\mathrm{HO}$ of Palaeotetradinium minusculum is observed below the LO of $T$. bramlettei and the HOs of $A$. paniculatum and $A$. homomorphum are above the LO of $T$. bramlettei.

The LO of the key-species Dracodinium simile (sample 331), determining the base of the Dracodinium simile Zone of eastern Peri-Tethys (Iakovleva, 2017), Western Siberia (Iakovleva and Aleksandrova, 2013) and NW Europe (Powell, 1992), is found coinciding with the $\mathrm{HO}$ of Tribrachiatus digitalis (the base of NP10c). In the other NE Peri-Tethyan key lower Eocene sections like Aktulagay (Kazakhstan) and Suvlu-Kaya (Crimea), the LO of Dr. simile is found in the same interval (upper NP10), supporting the stratigraphical importance of this dinocyst event (King et al., 2013, 2018). The LOs of Dolichodinium uncinata and Deflandrea heteroplycta are revealed within the upper Abaza Fm. (sample 335) in the interval of nannofossil NP10c subzone. The HO of Dr. astra coincides with the LO of nannofossil T. contortus.

The base of the Cherkessk Fm. (sample 735B) is characterized by the LOs of Dracodinium varielongitudum and Membranophoridium perforatum, just above the LO of Tribrachiatus orthostylus, marking the base of CNE3 zone and HO of T. contortus, marking the bases of NP11 zone and CP9b subzone. Species Petalodinium robertknoxii is recognized from the sample $738 \mathrm{~A}$ in the upper part of NP11 zone. The LO of Dracodinium robertknoxii seems to be synchronous with the LO of this species in Aktukagay (Kazakhstan, King et al., 2013) and in Suvlu-Kaya (Crimea, King et al., 2018), where it occurs also close to the NP11/NP12 boundary. The LO of $D r$. varielongitudum determines the base of the Dracodinium varielongitudum in eastern Peri-Tethys (Iakovleva, 2017), NW Europe (Köthe, 2012; Powell, 1992) and Western Siberia (Iakovleva and Aleksandrova, 2013).

A noteworthy fact is that the LO of Eatonicysta ursulae marks the base of the Eatonicysta ursulae Zone in the eastern Peri-Tethys (Kazakhstan) bounded by the Dracodinium simile and Dracodinium varielongitudum Zones (Iakovleva, 2017; King et al., 2013). However, in the Kheu section, E. ursulae is revealed belatedly and sporadically only within the Dracodinium varielongitudum Zone interval and its true lowermost occurrence seems to be missed.

The next part of the Cherkessk Fm. between samples 744 and $745 \mathrm{~A}$ contains taxonomically poor dinocyst assemblage, dominated by Achomosphaera ramulifera and Spiniferites ramosus, and did not reveal stratigraphically important species Charlesdowniea coleothrypta, Petalodinium condylos, or Rhadinodinium politum. Consequently, this interval of the section remains unclear: it corresponds either to the Charlesdowniea coleothrypta Zone or to the upper part of the Dracodinium varielongitudum Zone. Taking into account that the nannofossil record does not suggest the occurrence of any significant stratigraphical hiatus, it is most probably that the true LO of Ch. coleothrypta is missed due to some facies unfavorability that is indicated by very low abundance of wetzelielloids. 
The key-species Ochetodinium romanum as well as Cerebrocysta bartonensis and Memranilarnacia compressa first occur in the sample 745B. The LO of Och. romanum is found here in the middle CP10 zone. The LO of stratigraphically important Samlandia chlamydophora and the HO of Deflandrea oebisfeldensis are revealed in the sample 746B and coincide with the LOs of Coccolithus crassus and the base of CP11 zone. It is noteworthy that the lowermost for this section (but not the true LO) common occurrence of Sophismatia crassoramosa (up to $\sim 7 \%$ of the dinocyst assemblage) is documented slightly above the LO of $S$. chalmydophora and its HO is recognized in the sample 759 (the upper part of NP12 zone). It was largely considered previously that $S$. crassoramosa, occurring first during the early Ypresian, has a very short stratigraphic range and disappears within the NP10 Zone interval. Our record from the Kheu section suggests a wider stratigraphical interval for this species. The LOs of species Pentadinium laticinctum and Membranilarnacia glabra (sample 7) are recognized in the upper parts of NP12 and CNE4 nannofossil. Stratigraphically important species Piladinium columna, which true LO is usually between the LOs of Och. romanum and S. chamydophora (Iakovleva and Aleksandrova, 2013; Iakovleva, 2017), has a belated first occurrence in the Kheu section (sample 6). Successive LOs of Och. romanum and S. chlamydophora allow us to attribute this part of the Cherkessk Fm. to the Ochetodinium romanum/Samlandia chlamydophora Zone of eastern Peri-Tethys (Iakovleva, 2017), which is also known in Western Siberia (Iakovleva and Aleksandrova, 2013). It corresponds to both Ochetodinium romanum and Kisselevia aff. clathrata zones interval in Belgian Basin (De Coninck, 1991) and to the D8b-c subzones of NW Europe (Costa and Manum, 1988).

A number of stratigraphically important species, characterizing the lower Ypresian levels ( $P$. condylos, $C$. bartonensis, Rh. politum, Charlesdowniea coleothrypta, Epelidinium? translucidum, Sophismatia? insolens, and Diphyes ficusoides), showed their late LOs in the Kheu section, falling into the interval of the Ochetodinium romanum/Samlandia chlamydophora Zone. Thus, their true LOs are not recognized in this section.

The succession of the LOs of dinocyst key-species is recognized within the upper Cherkessk Fm. Thus, the LO of Areosphaeridium diktyoplokum (sample 21) corresponds to the HO of nannofossil Tribrachiatus orthostylus, which defines the base of NP13 Zone. This bioevent is followed by LOs of Thalassiphora dominiquei and Dracodinium coronatum (sample 22), Diphyes brevispinum (sample 23), and Areosphaeridium michoudii (sample 24). The HO of Deflandrea denticulata is observed in the sample 32. The LO of Areosphaeridium diktyoplokum defines the base of the Areosphaeridium diktyoplokum Zone in the eastern Peri-Tethys (Iakovleva, 2017), Western Siberia (Iakovleva and Aleksandrova, 2013) and Denmark (Heilmann-Clausen and Costa, 1989). The Peri-Tethyan Areosphaeridium diktyoplokum Zone corresponds to the part of the NW European D9 Zone (Costa and Manum, 1988), the interval of three zones in Belgium (Areosphaeridium diktyoplokum, Paucilobimorpha triradiata, Litosphaeridium mamellatum; De Coninck, 1991), the part of the E2c Subzone in the North Sea (Mudge and Bujak, 1994), and the part of the B-2 Zone of southern England (Bujak et al., 1980). Similarly to the dinocyst record of the key lower Eocene Peri-Caspian Aktulagay section (Kazakhstan, King et al., 2013) and in the West European sections (Steurbaut, 1998), the LO of Ar. diktyoplokum almost coincides with the base of NP13 Zone in the Kheu section, while the LO of Thalassiphora dominiquei is very close to this level.

The LOs of stratigraphically important species Duosphaeridium nudum and Dracodinium? brevicornutum are recognized in the uppermost part of the studied interval of Cherkessk Fm., within the last sapropelitic bed. At Aktulagay section, these species occur slightly before the first occurrence of key-species Dracodinium eocaenicum, which characterizes the uppermost Ypresian (the base of NP14 Zone), while in Western Siberia D. nudum and Dr.? brevicornutum are revealed simultaneously with Dracodinium eocaenicum (Iakovleva and Aleksandrova, 2013). In the Kheu section, the lowermost occurrences of D. nudum and Dr.? brevicornutum are constrained to within the NP13 Zone interval, similarly to the record found in Kazakhstan (King et al., 2013).

\section{DISCUSSION AND CONCLUSIONS}

The lower Eocene sediments of the Kheu section consist of two lithostratigraphic units (Abaza Fm. and Cherkessk Fm.). Their sedimentological peculiarities can be interpreted in response to regional paleogeographic changes. The accumulation of Abaza Fm. represents an interruption of the carbonate shelf sedimentation of the earliest Eocene (the uppermost Nalchik Fm.). It was caused by the extensive input of clayey material, likely due to the significant sea-level fall of the lowermost Eocene (see Fig. 3) and dramatically increased river discharge from the neighboring island. These paleoenvironmental changes negatively affected calcareous microbiota -the main $\mathrm{CaCO}_{3}$ supplier into the sediment- which displays very gradual restoration in abundance after their dramatic elimination from the lower part of Abaza Fm. Nannofossils recovered earlier than foraminifera restoration and formed the main calcareous component of the mostly siliciclastic Abaza Fm. (see Fig. 4B), while foraminifera 
reappeared in the upper part of this Formation only. The combining foraminifera-nannofossil component is the main constituting elements of the calcium carbonate in the Cherkessk Fm. These variations in microfossil abundance and diversity likely reflect the variations in the basin depth, changes of the source area of eroded and transported into the basin sediments and, thus, the supply of nutrients for microorganisms during the early Eocene. The maximum depth of this part of $\mathrm{N}$ Caucasian basin during Ypresian was likely likey achieved during the formation of the highly calcareous compact pink marl in the middle of the Unit 1 between 28 and $31 \mathrm{~m}$ (see photographs in Figs. 2; 4) marked by the highest nannofossil and foraminifera abundance. Many shallow basins of the NE Peri-Tethys margin display hiatus or shallowing upward sequences ranging the upper Ypresian interval (Muzylöv, 1994). The sediments of the Unit 2 of Cherkessk Fm. are supposed to be accumulated during the regressive trend corresponding to the long-lived eustatic sea-level fall (Miller et al., 2005), that is supported by coarsening of siliciclastic component in this part of section and reduced abundance of planktonic microbiota.

The different number of TOC-rich layers is documented throughout a wide territory of the NE Peri-Tethys in the upper part of the Ypresian (Muzylöv, 1994). The Kheu section, located in the deepest part of this paleo-basin, displays the highest number of TOC-rich layers and highest TOC enrichment showing the most complete record of the paleoenvironmental changes during this time span (upper NP12-lower NP13 nannofossil zones) evidently related to the Early Eocene Climatic Optimum. Short regressive pulses suggested by the increase of glauconite concentrations and reduced nannofossil abundance preceded the formation of each TOC-rich sapropelite interval (Fig. 4E; 5) during the following short transgression pulses (see Fig. 3).

The high-resolution study of the lower Eocene microfossils enabled the direct calibration between nannofossil and dinocyst bioevents. Despite the wide variations in the nannofossil abundance throughout the section, the representativeness of nannofossil assemblages enabled the use of three complimentary nannofossil zonations (Agnini et al., 2014; Martini, 1971; Okada and Bukry, 1980) that provided a detailed biostratigraphy of the studied succession. The series of dinocyst bioevents revealed in the lower Eocene of the Kheu section led to recognize eight dinocyst zones previously established in the NE PeriTethys and NW Europe: Axiodinium augustum, Deflandrea oebisfeldensis, Dracodinium astra, Dracodinium simile, Stenodinium meckelfeldense, Draconidium varielongitudum, Ochetodinium romanum/Salmandia chlamydophora and Aerosphaeridium diktyoplokum (see Fig. 5). The true LOs of nominative species for two Ypresian Peri-Tethyan zones (Eatonicysta ursulae and Charlesdowniea coleothrypta) have not been recognized in the Kheu section, probably due to the peculiarities of facies and dinocyst assemblages. Nevertheless, dinocyst data indicate quite continuous character of the early-mid Ypresian sedimentation.

Generally, both nannofossils and dinocysts show very high dynamics in the species first appearances/disappearances around the SPB corresponding to the global PETM event, and just above it in the interval of the late phase of the CIE (Shcherbinina et al., 2016). Above this level, the renovation of nannofossil assemblage is mostly related to the radiation of short-lived species (Tribrachiatus and Coccolithus linages), reflecting the environmental specificity worldwide during the earliest Eocene. In the basin of the central northern Caucasus, the large-scale supply of siliciclastic material oppressed calcareous microbiota and caused the bloom of siliceous (radiolarian and diatoms) and organicwalled (dinoflagellates) microorganisms, sustained by the increased nutrient availability. The palynomorph assemblage from the post-PETM interval (part of NP9c) shows the absolute domination of dinocysts ( $100 \%)$ within the uppermost Nalchik and the whole Abaza fms. In its turn, the dinocyst assemblage within this whole interval (Deflandrea oebisfeldensis-Dracodinium astraStenodinium meckelfeldense zones) is clearly dominated by Spiniferites/Achomosphaera-group, indicating the restoration of the open-marine shelf environments after the PETM and during the post-PETM time. This suggests small-scale, albeit long-lived, sea-level fall in the basin and evidences that facies change has much more crucial effect on calcareous microbiota than water depth changes. Wide occurrence of siliceous microorganisms and dinoflagellates and domination of mesotrophic/euthrophic Toweius in nannofossil assemblage of Abaza Fm. both indicate high nutrition level during the early Ypresian time. The high ratio of warm-water Discoaster and cool-water Chiasmolithus suggests rather warm conditions.

In the middle Ypresian (NP11-12), the high turnover rate in nannofossil assemblage of the northern Caucasus is mainly derived from the extensive radiation in Sphenolithus lineages and first appearance of new species of Discoaster, Toweius, Helicosphaera and Girgisia (14 new nannofossil taxa), while many Paleocene survivors become extinct. This increased dynamics of the changes in the nannofossil assemblage more likely reflects initial environmental variations possibly corresponding to the minor lower Eocene hyperthermals (Nicolo et al., 2010; D'Onofrio et al., 2016; Sexton et al., 2011; among others) occurred during this time-span. The dinocyst taxonomic diversity and prominent fluctuations of different dinocyst eco-groups (wetzelielloids, deflandroids, Homotryblium-, Areoligera-, Spiniferites-groups, Impagidinium) increases from the beginning of the Cherkessk Fm. (Dracodinium varielongitudum Zone, NP11 Zone), that also confirms 
environmental fluctuations in the basin. The next part of the Cherkessk Fm. (conceivably Charlesdowniea coleothrypta Zone interval), is characterized by a very scarce dinocysts and, therefore, suggests the maximal deepening of the basin, already confirmed by highest nannoplankton and foraminifera abundance in the calcareous marl of this interval.

The very high diversification rate is detected in the interval of NP12 nannofossil Zone and Ochetodinium romanum/Samlandia chlamydophora dinocyst Zone, where many nannofossil and dinocyst taxa have their LOs, including the LOs of important upper Cenozoic nannofossil genera Reticulofenestra and Cyclicargolithus. This bloom in microfossil diversity during the mid-Ypresian, recognized in the Kheu section, is typical for many other regions of marine sedimentation (North Sea Basin, PeriTethys, Western Siberia) and was more likely governed by the paleoenvironmental instability during the EECO that caused variations in the sedimentary environment and occurrence of multiple ecological niches. In the topmost part of studied interval (NP13 zone), both microfossil groups display low turnover dynamics in the microfossil assemblages that likely suggests environmental stabilization also known for many other West Eurasian regions.

\section{ACKNOWLEDGMENTS}

We thank G.N. Aleksandrova (Geological Institute of the Russian Academy of Sciences) for her help in chemical palynological preparation and anonymous reviewer for important comment, helping to improve the manuscript. This work was made following the plans of scientific research of the Geological Institute of RAS (projects nos. 0135-2019-0062, 0135-2019-0044 and 0135-2019-0070) and was partially supported by the Presidium of RAS Program no. 0135-2018-0051.

\section{REFERENCES}

Agarkov, Yu.V., Boyko, N.I., Sedletsky, V.I., 1989. Siliceous sediments of the northern Caucasus and perspectives of their use. Publishing of the Rostov-na-Donu University, 203pp.

Agnini, C., Fornaciari, E., Raffi, I., Catanzariti, R., Pälike, H., Backman, J., Rio, D., 2014. Biozonation and biochronology of Paleogene calcareous nannofossils from low and middle latitudes. Newsletters on Stratigraphy, 47(2), 131-181.

Aubry, M.-P, Salem, R., 2012. The Dababiya Quarry Core: coccolith biostratigraphy. Stratigraphy, 9(3-4), 241-259.

Beniamovski, V.N., 2001. Substantiation of the detailed stratigraphic scheme of the lower Paleogene of the CrimeaCaucasus area. In: Gladenkov, Yu.B., Kuznetsova, K.I. (eds.). Towards detailed stratigraphic schemes and paleogeographic reconstructions (in Russian). Moscow, GEOS, 210-223.
Beniamovski, V.N., Alekseev, A.S., Ovechkina, M.N., Oberhänsli, H., 2003. Middle to upper Eocene dysoxic-anoxic Kuma Formation (northeastern Peri-Tethys): Biostratigraphy and paleoenvironments. In: Wing, S.L., Gingerich, P.D., Schmitz, B., Thomas, E. (eds.). Causes and Consequences of Globally Warm Climates in the Early Paleogene. Boulder (Colorado), Geological Society of America Special Paper, 369, 95-112.

Beniamovskiy, V., 2011. A high resolution Lutetian-Bartonian planktonic foraminiferal zonation in the Crimean-Caucasus region of the northeastern Peri-Tethys. Austrian Journal of Earth Sciences, 105/1, 117-128.

Bown, P.R., Young, J.R., 1998. Techniques. In: Bown, P.R. (ed.). Calcareous Nannofossil Biostratigraphy. British Micropalaeontological Society Publication Series, Chapman and Hall (Kluwer Academic Publishers), 16-28.

Bugrova, E.M., Nikolaeva, I.A., Panova, L.A., Tabachnikova I.P., 1988. Zonal subdivision of the Paleogene of the South USSR (in Russian). Sovietskaya geologia, 4, 96-107.

Bujak, J.P., Downie, D., Eaton, G.L., Williams, G.L., 1980. Dinoflagellate cysts and acritarchs from the Eocene of southern England. Special Papers in Palaeontology, 24, 100pp.

Costa, L.I., Manum, S.B., 1988. The distribution of the interregional zonation of the Paleogene (D1-D15) and the Miocene (D16-D20). In: Vinkin, R. (ed.). The Northwest European Tertiary Basin. Results of the International Geological Correlation Programme, Project 124. Geologisches Jahrbuch, Reihe B.A, 100, 321-330.

Crouch, E.M., Heilmann-Clausen, C., Brinkhuis, H., Morgans, H.E., Rogers, K.M., Egger, H., Schmitz, B., 2001. Global dinoflagellate event associated with the late Paleocene thermal maximum. Geology, 29, 315-318.

De Coninck, J., 1991. Ypresian organic-walled phytoplankton in the Belgian Basin and adjacent areas. In: Dupuis, C., De Coninck, J., Steurbaut, E. (eds.). The Ypresian stratotype. Bulletin de la Sociéte Belge de Géologie, 97, 287-319.

D’Onofrio, R., Luciani, V., Fornaciari, E., Giusberti, L., Boscolo Galazzo, F., Dallanave, E., Westerhold, T., Sprovieri, M., Telch, S., 2016. Environmental perturbations at the early Eocene ETM2, $\mathrm{H} 2$, and I1 events as inferred by Tethyan calcareous plankton (Terche section, northeastern Italy). Paleoceanography, 31, 1225-1247. DOI: 10.1002/2016PA002940

Gavrilov, Yu.O., Muzylev, N.G., 1991. The geochemistry of sapropelitic interbeds in Paleogene of the Central Caucasus. Lithology and Mineral Resources, 26(6), 548-559.

Gavrilov, Yu.O., Shcherbinina, E.A., Muzylöv, N.G., 2000. A Paleogene sequence in central North Caucasus: A response to paleoenvironmental changes. GFF, 122, 51-53.

Gavrilov, Yu.O., Shcherbinina, E.A., Oberhänsli, H., 2003. Paleocene/Eocene boundary events in the northeastern PeriTethys. In: Wing, S.L., Gingerich, P.D., Schmitz, B., Thomas, E. (eds.). Causes and Consequences of Globally Warm Climates in the Early Paleogene. Boulder (Colorado), Geological Society of America Special Paper, 369, 147-168.

Gavrilov, Yu.O., Shcherbinina, E., Golovanova, O., Pokrovsky, B., 2009. A Variety of PETM Records in Different Settings 
of Northeastern Peri-Tethys. In: Crouch, E.M., Strong, C.P., Hollis, C.J. (eds.). Climatic and Biotic Events of the Early Paleogene (CBEP 2009). Wellington (New Zealand), 1215 January 2009, Extended Abstracts from an International Conference, GNS Science Miscellaneous Series, 18, 67-70.

Heilmann-Clausen, C., 1985. Dinoflagellate stratigraphy of the uppermost Danian to Ypresian in the Viborg 1 borehole, central Jylland, Denmark. Danmarks Geologiske Undersogelse. Serie A, 7, 69pp.

Heilmann-Clausen, C., Costa, L.I., 1989. Dinoflagellate zonation of the uppermost Paleocene? to Lower Miocene in the Wursterheide Research Well, NW Germany. Geologisches Jahrbuch, 111, 431-521.

Heilmann-Clausen, C., 1994. Review of Paleocene dinoflagellates of the North Sea Region. GFF, 116, 51-53.

Iakovleva, A.I., Aleksandrova, G.N., 2013. About the question of updating the Paleocene-Eocene dinocyst zonation of Western Siberia (in Russian). Bulletin of Moscow Society of Naturalists, Geological Series, 88(1), 59-82.

Iakovleva, A.I., 2017. Detalization of Eocene dinocyst zonation for Eastern Peritethys (in Russian). Bulletin of Moscow Society of Naturalists, Geological Series, 92(2), 32-48.

Iakovleva A.I., Vaga D.D., Andreeva-Grigorovich, A.S., Radionova, E.P., in press. New palynological data from the Mid Eocene sediments of the Kheu River key-outcrops (KabardinoBalkaria, Northern Caucasus). Stratigraphy and Geological Correlation.

King, Ch., Iakovleva, A.I., Steurbaut, E., Heilmann-Clausen, C., Ward, D., 2013. The Aktulagay section, west Kazakhstan: a key site for northern mid-latitude early Eocene stratigraphy. Stratigraphy, 10(3), 171-209.

King, Ch., Iakovleva, A.I., Heilmann-Clausen, C., Steurbaut, E., 2018. Early Eocene stratigraphy of the Suvlu-Kaya reference section in the Bakhchisaray area (Crimea). Newsletters on Stratigraphy, 51(2), 167-208.

Köthe, A., 2012. A revised Cenozoic dinoflagellate cyst and calcareous nannoplankton zonation for the German sector of the southeastern North Sea Basin. Newsletters on Stratigraphy, 45(3), 189-220.

Krasheninnikov, V.A., Muzylöv, N.G., 1975. Correlation of the planktonic foraminifera and nannofossil zonations in the Paleogene northern Caucasus sections (in Russian). Micropaleontological Issues (Voprosy mciropaleontologii), 18, 212-224.

Leonov, G.P., Alimarina, V.P., 1964. The problems of the lower Paleogene stratigraphy of the northern Caucasus. Moscow, Moscow University Publishing, 203pp.

Martini, E., 1971. Standard Tertiary and Quaternary calcareous nannoplankton zonation. In: Farinacci, A. (ed.). Proceedings of the 2nd Planktonic Conference on Planktonic Microfossils Roma. Tecnoscienza, Roma (2), 739-785.

Miller, K.G., Kominz, M.A., Browning, J.V., Wright, J.D., Mountain, G.S., Katz, M.E., Sugarman, P.J., Cramer, B.S., Christie-Blick, N., Pekar, S.F, 2005. The Phanerozoic record of global sealevel change. Science, 310(5752), 1293-1298.
Mudge, D.C., Bujak, J.P., 1994. Eocene stratigraphy of the North Sea Basin. Marine and Petroleum Geology, 11, 166-181.

Mudge, D.C., Bujak, J.P., 1996. An integrated stratigraphy for the Paleocene and Eocene of the North Sea. In: Knox, R.W.O'B., Corfield, R.M., Dunay, R.E. (eds.). Correlation of the Early Paleogene in Northwest Europe. Geological Society, London. Special Publications, 101, 91-113.

Muzylöv, N.G., 1980. Paleogene nannofossil stratigraphy of the south of the USSR (northern Caucasus and Crimea). Moscow, Transactions of the Geological Institute of USSR, 384, 94pp.

Muzylöv, N.G., 1994. Paleocene-Middle Eocene Anoxic Events. In: Rozanov, A.Yu., (ed.). Ecosystem Reorganization and Biosphere Evolution (in Russian). Moscow, Nedra, 1, 160-166.

Nicolo, M.J., Dickens, G.R., Hollis, C.J., Zachos, J.C., 2010. Multiple early Eocene hyperthermals: Their sedimentary expression on the New Zealand continental margin and in the deep sea. Geology, 35(8), 699-702. DOI: 10.1130/G23648A.1

Okada, H., Bukry, D., 1980. Supplementary modification and introduction of code numbers of the lowlatitude coccolith biostratigraphic zonation (Bukry 1973, 1975). Marine Micropalaeontology, 5, 321-325.

Powell, A.J., 1992. A Stratigraphic Index of Dinoflagellate cyst. British Micropaleontological Society Publication Series, 290pp.

Powell, A.J., Brinkhuis, H., Bujak, J.P., 1996. Upper Paleocenelower Eocene dinoflagellate cyst sequence biostratigraphy of southeast England. In: Knox, R.W.O'B., Corfield, R.M., Dunay, R.E. (eds.). Correlation of the Early Paleogene in Northwest Europe. Geological Society, 101 (Special Publications), 145-183.

Radionova, E.P., Khokhlova, I.E., 1994. Paleogene episodes of biogenic silica accumulation in the northern Caucasus and adjacent Tethyan regions. Stratigraphy and Geological Correlation, 2(5), 161-169.

Radionova, E.P., Aleksandrova, G.N., Gavtadze, T.T., Stupin, S.I., Khokhlova, I.E., 2009. Analysis of Late Paleocene-Early Eocene Micropankton from the Kheu River Section, West PreCaucasus. In: Crouch, E.M., Strong, C.P., Hollis, C.J. (eds.). Climatic and Biotic Events of the Paleogene (CBEP 2009). Wellington (New Zealand), 12-15 January 2009, Extended Abstracts from an International Conference, GNS Science Miscellaneous Series, 18, 111-116.

Sexton, P.F, Norris, R.D., Wilson, P.A., Pälike, H., Westerhold, T., Röhl, U., Bolton, C.T., Gibbs, S., 2011. Eocene global warming events driven by ventilation of oceanic dissolved organic carbon. Nature, 471, 349-353.

Shcherbinina, E., Gavrilov, Yu., Iakovleva, A., Pokrovsky, B., Golovanova, O., Aleksandrova, G., 2016. Environmental dynamics during the Paleocene-Eocene thermal maximum (PETM) in the northeastern Peri-Tethys revealed by highresolution micropalaeontological and geochemical studies of a Caucasian key section. Palaeogeography, Palaeoclimatology, Palaeoecology, 456, 60-81. 
Shutskaya, E.K., 1960. Stratigraphy and facies of the lower Paleogene of the Cis-Caucasia (in Russian). Moscow, Gostoptekhizdat, 230pp.

Steurbaut, E., 1998. High-resolution holostratigraphy of Middle Paleocene to early Eocene strata in Belgium and adjacent seas. Palaeontographica, A 247, 91-156.

Subbotina, N.N., 1947. Foraminifera of the Danian and Paleogene sediments of the northern Caucasus. In: Microfauna of the Caucasus, Emba Reaches and Central Asia (in Russian). Leningrad, Lengostoptekhizdat, 39-160.
Williams, G.L., Fensome, R.A., MacRae, R.A., 2017. The Lentin and Williams index of fossil dinoflagellates 2017 edition. American Association of Stratigraphic Palynologists Contributions Series, 48, 1097pp.

Zaporozhets, N.I., 2001. Palynological assemblages from the Mid Eocene Kuma Formation of Caucasus and its age analogues in adjacent regions. Stratigraphy \& Geological Correlation, 9(6), 83-103.

Manuscript received June 2019;

revision accepted October 2019;

published Online January 2020. 


\section{APPENDIX I}

TABLE I. The nannofossil range chart of the lower Eocene sediments of the Kheu section (6 parts). 1: zones of Martini, 1971; 2: zones of Okada and Bukry, 1980; 3: zones of Agnini et al., 2014. Sapropelite intercalations are shown in gray

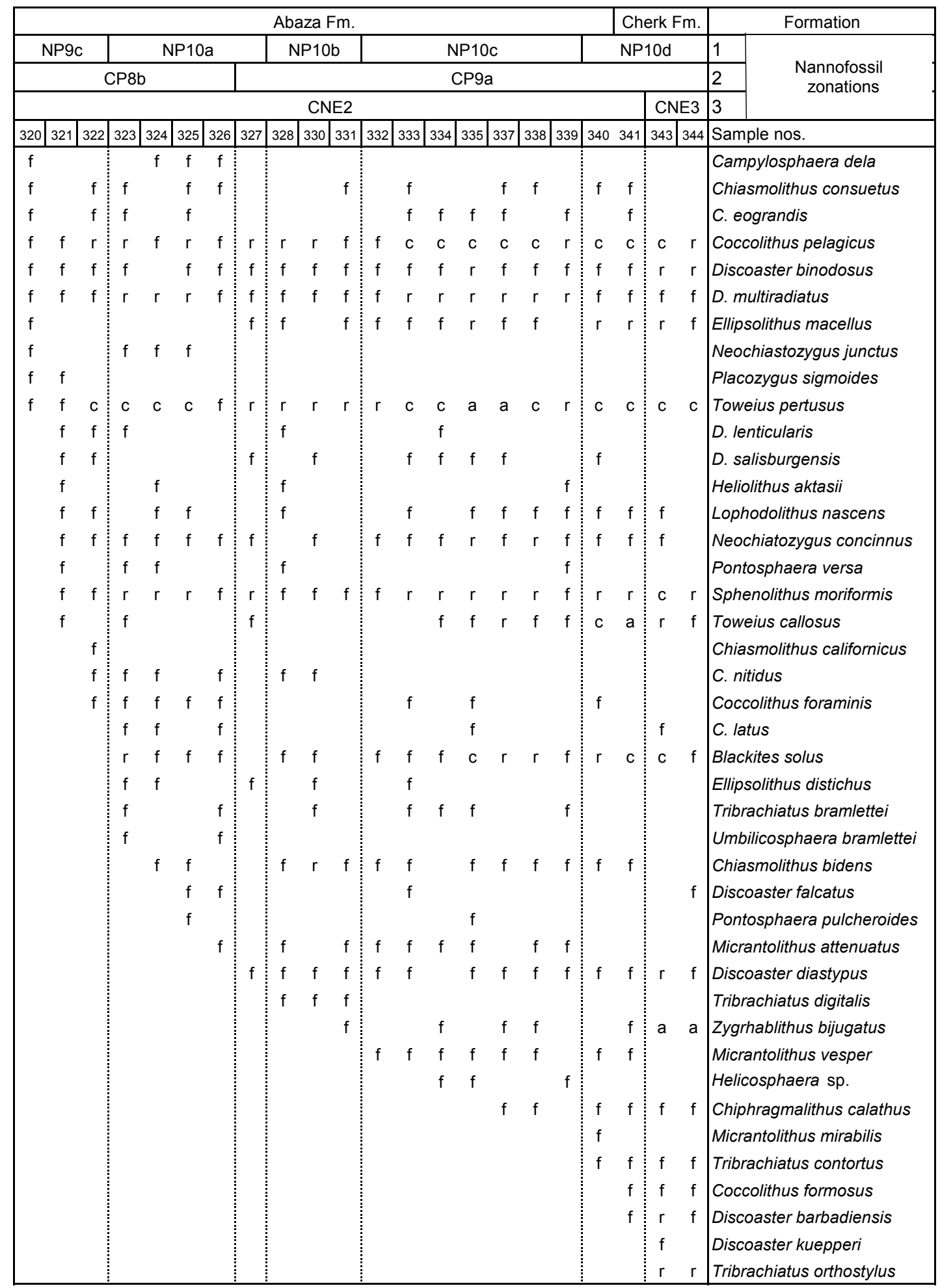


TABLE I cont.

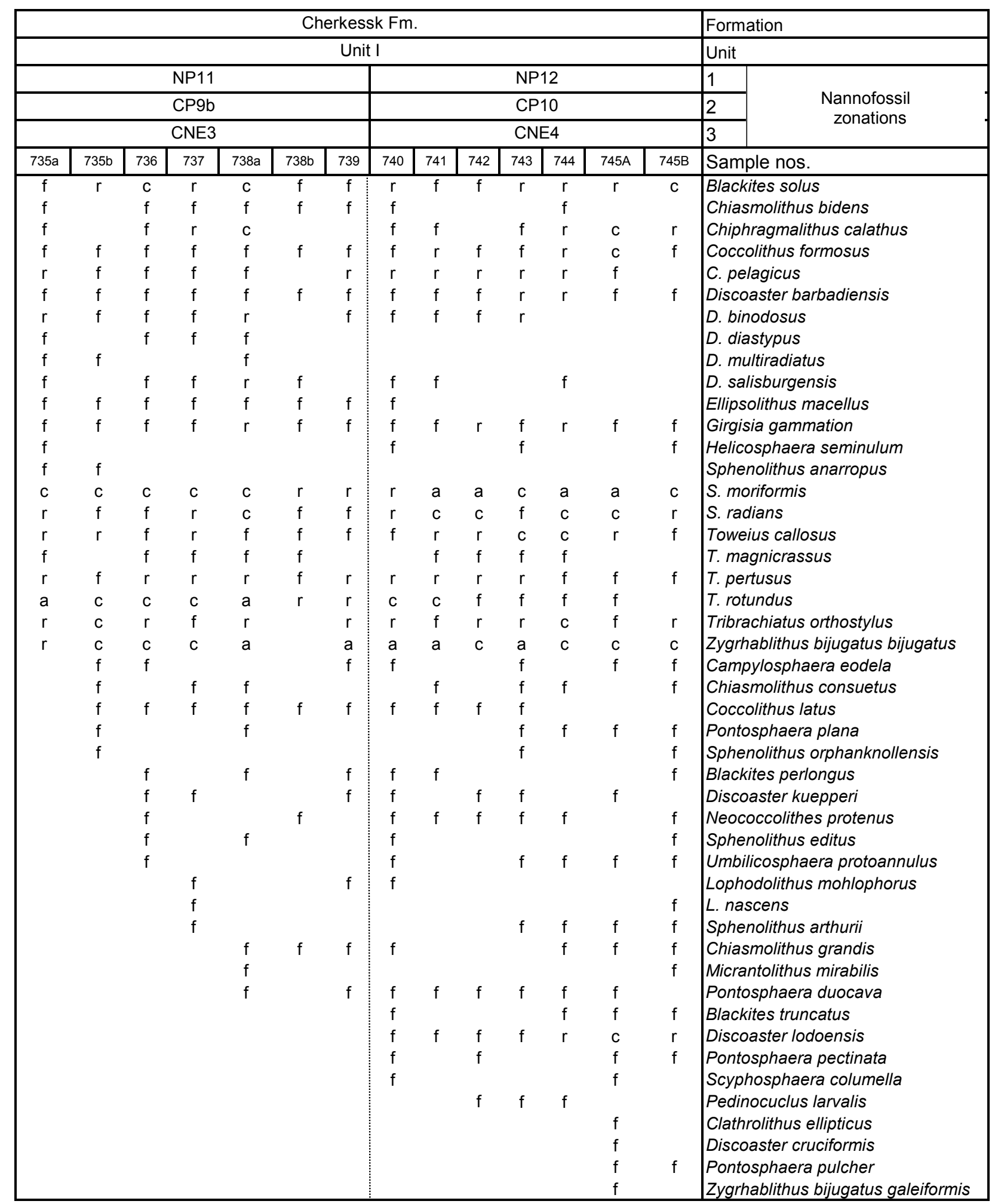




\section{TABLE I cont.}

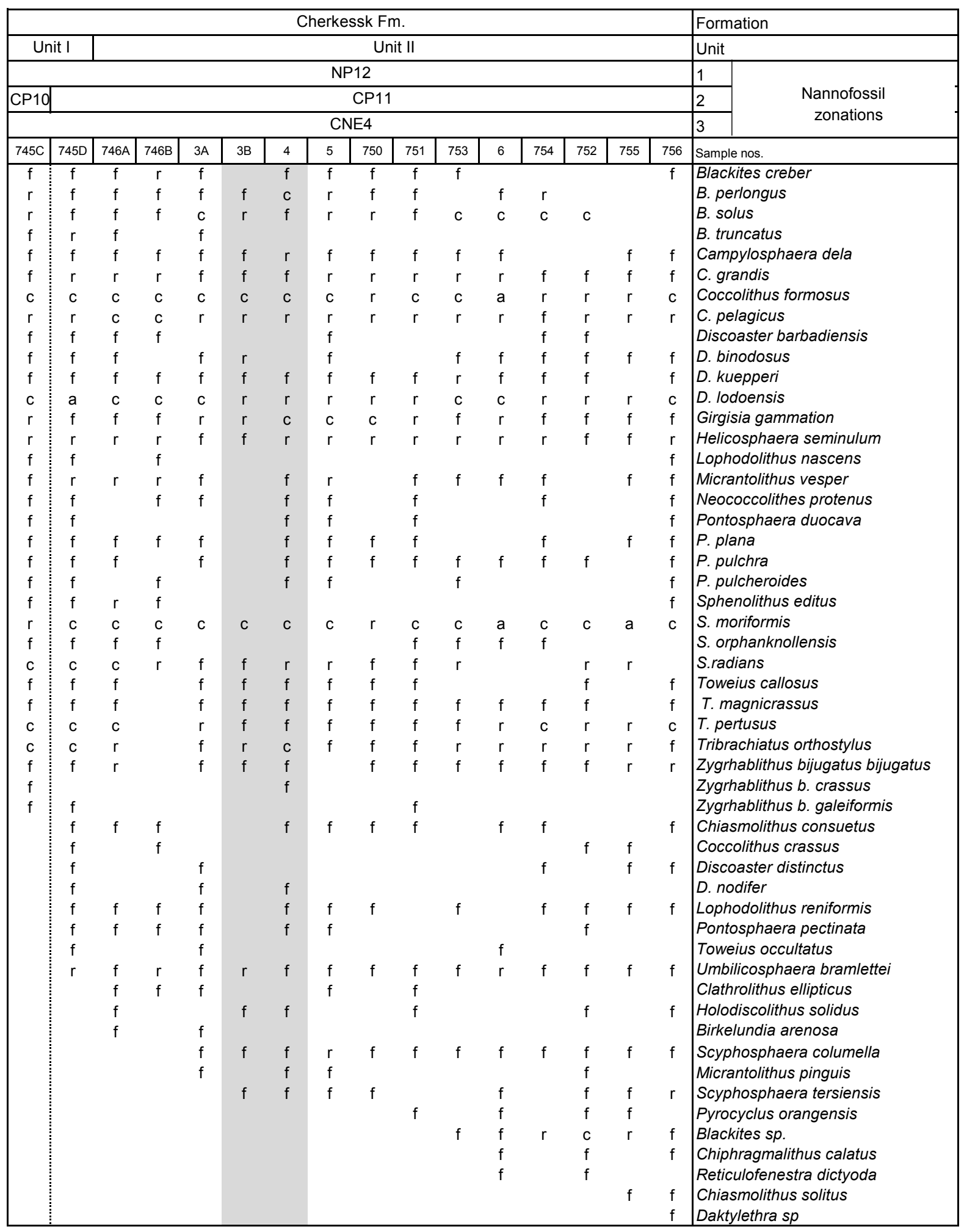


TABLE I cont.

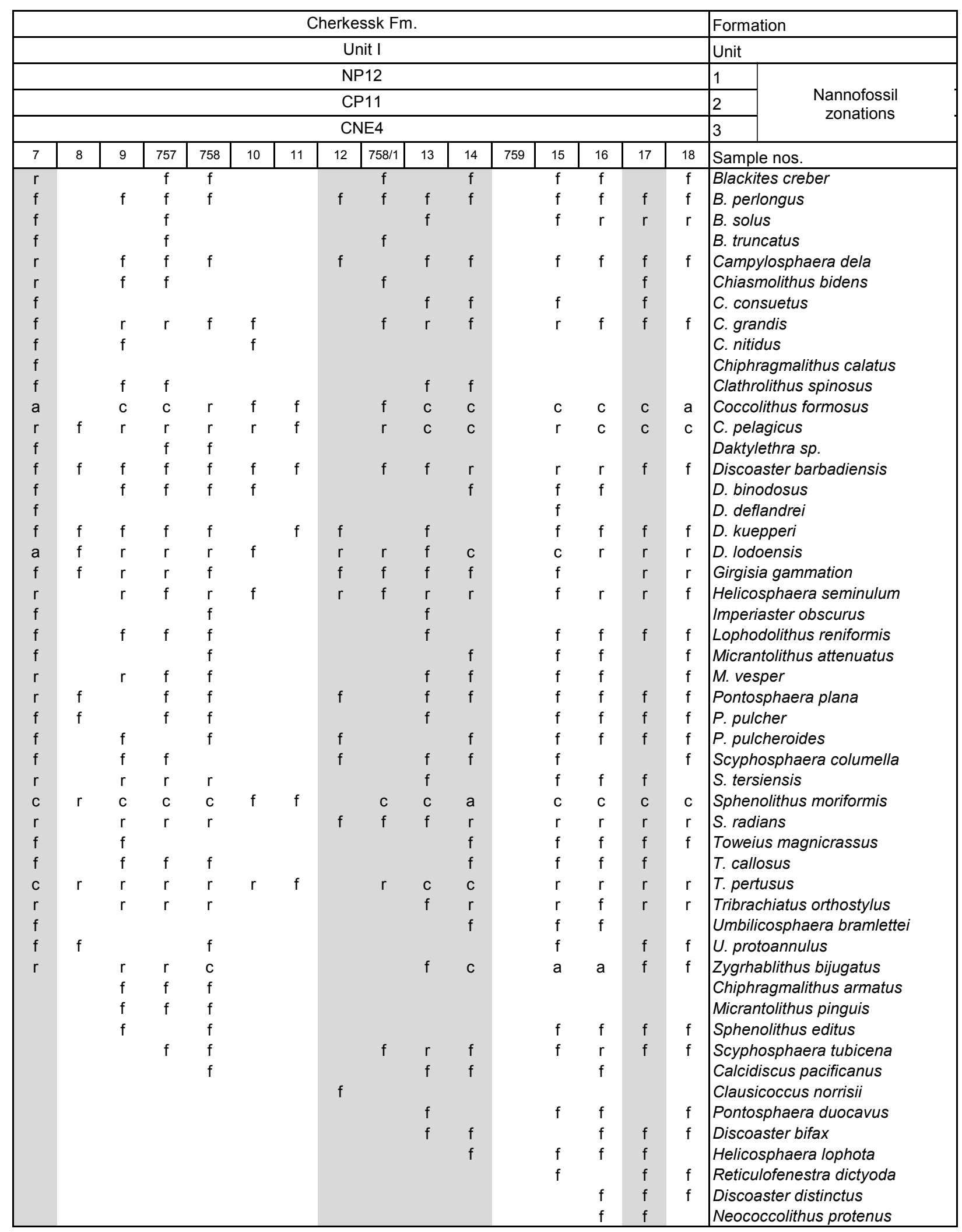




\begin{tabular}{|c|c|c|c|c|c|c|c|c|c|c|c|c|c|}
\hline \multicolumn{12}{|c|}{ Cherkessk Fm. } & \multicolumn{2}{|c|}{ Formation } \\
\hline \multicolumn{12}{|c|}{ Unit II } & \multicolumn{2}{|c|}{ Unit } \\
\hline \multicolumn{4}{|c|}{ NP12 } & \multicolumn{8}{|c|}{ NP13 } & 1 & \multirow{3}{*}{$\begin{array}{c}\text { Nannofossil } \\
\text { zonations }\end{array}$} \\
\hline \multicolumn{12}{|c|}{ CP11 } & 2 & \\
\hline \multicolumn{4}{|c|}{ CNE4 } & \multicolumn{8}{|c|}{ CNE5 } & 3 & \\
\hline 42 & 43 & 44 & 20 & 21 & 22 & 23 & 24 & 25 & 26 & 27 & 28 & \multicolumn{2}{|c|}{ Sample nos. } \\
\hline $\bar{f}$ & $\bar{f}$ & & $f$ & $\bar{f}$ & \multirow[t]{2}{*}{$r$} & \multirow[t]{2}{*}{$r$} & $r$ & $r$ & $r$ & $\bar{f}$ & $r$ & & creber \\
\hline c & $r$ & $f$ & $r$ & $f$ & & & & & & & & & \\
\hline$f$ & $f$ & $f$ & & $f$ & & $\mathrm{f}$ & $f$ & $f$ & f & $\mathrm{f}$ & $f$ & & sphaera dela \\
\hline$f$ & & $f$ & & & & & $f$ & $f$ & & & & & lithus bidens \\
\hline $\mathrm{f}$ & & & & & & & & & & & & & Ietus \\
\hline$r$ & $\mathrm{f}$ & $f$ & & $\mathrm{f}$ & $f$ & $f$ & $r$ & $f$ & f & $\mathrm{f}$ & $f$ & & \\
\hline c & c & c & c & c & c & c & c & $r$ & c & c & $r$ & & hus formosus \\
\hline c & c & $r$ & c & c & c & c & c & c & c & c & c & & \\
\hline$r$ & $r$ & $f$ & $r$ & $\mathrm{f}$ & $\mathrm{f}$ & $\mathrm{f}$ & $f$ & $f$ & f & $r$ & $r$ & & ter barbadiensis \\
\hline $\mathrm{f}$ & $\mathrm{f}$ & $f$ & $\mathrm{f}$ & $f$ & & & & $f$ & & $\mathrm{f}$ & & & \\
\hline $\mathrm{f}$ & $r$ & $r$ & $r$ & $r$ & $\mathrm{f}$ & $r$ & $r$ & $f$ & $f$ & $r$ & $r$ & & losus \\
\hline$f$ & & $f$ & $f$ & $f$ & $f$ & & & & & $r$ & & & רdrei \\
\hline$f$ & $\mathrm{f}$ & $f$ & $f$ & & & $\mathrm{f}$ & $\mathrm{f}$ & $f$ & & $f$ & & & oeri \\
\hline c & c & c & $r$ & $r$ & $r$ & c & c & c & c & c & c & & $n$ sis \\
\hline$r$ & c & $r$ & $r$ & c & $r$ & c & c & c & c & c & $r$ & & gammation \\
\hline$f$ & $f$ & & $f$ & $f$ & & r & & & f & & $f$ & & haera lophota \\
\hline$f$ & $r$ & $r$ & $r$ & c & $r$ & c & c & c & c & c & c & & ulum \\
\hline$f$ & $f$ & $f$ & & & & & & & & & & & lithus reniformis \\
\hline$f$ & $r$ & $f$ & $r$ & $r$ & $r$ & $r$ & C & C & $r$ & $r$ & & & lithus vesper \\
\hline$f$ & $f$ & & $f$ & $f$ & & $f$ & $f$ & & $f$ & $f$ & & & colithes protenus \\
\hline$f$ & $f$ & & $f$ & & $f$ & $f$ & & $f$ & & $f$ & $f$ & & haera duocavus \\
\hline$f$ & $f$ & $f$ & & $r$ & $f$ & $f$ & f & $f$ & f & $f$ & $f$ & & \\
\hline$f$ & $f$ & $f$ & $f$ & $f$ & $f$ & $f$ & $f$ & $f$ & $f$ & $f$ & $f$ & & \\
\hline$f$ & $\mathrm{f}$ & $f$ & & $\mathrm{f}$ & $f$ & $f$ & $f$ & $r$ & $f$ & $\mathrm{f}$ & & & eroides \\
\hline$f$ & $\mathrm{f}$ & $f$ & f & $f$ & & $f$ & & $f$ & & $\mathrm{f}$ & a & & phaera tubicena \\
\hline$f$ & $f$ & $f$ & r & $f$ & $f$ & r & C & c & c & $r$ & a & & ithus editus \\
\hline c & c & c & a & r & a & c & c & c & a & c & c & & ormis \\
\hline$f$ & $f$ & & & & & & & & & & & & inknollensis \\
\hline r & r & $r$ & c & $r$ & $r$ & $r$ & c & c & $r$ & c & $r$ & & \\
\hline$f$ & $f$ & & & & $f$ & & & & & & & & callosus \\
\hline$f$ & $r$ & $r$ & $r$ & $r$ & r & $r$ & $r$ & $r$ & $r$ & $r$ & $r$ & & icrassus \\
\hline$r$ & $r$ & $r$ & $\mathrm{r}$ & $\mathrm{r}$ & $\mathrm{r}$ & c & $r$ & c & $\mathrm{r}$ & c & & & \\
\hline $\mathrm{r}$ & $r$ & $f$ & $f$ & & & & & & & & & & iatus orthostylus \\
\hline$f$ & & & $f$ & & & $f$ & $\mathrm{f}$ & & & $f$ & & & sphaera bramlettei \\
\hline a & c & c & c & $\mathrm{f}$ & $r$ & $r$ & $r$ & $r$ & c & a & $r$ & & lithus bijugatus \\
\hline & $\mathrm{f}$ & & & & & $f$ & $f$ & $f$ & & $\mathrm{f}$ & & & lithus attenuatus \\
\hline & $f$ & $\mathrm{f}$ & & & & $f$ & $f$ & $f$ & & $f$ & & & ter cruciformis \\
\hline & $f$ & & & $f$ & & & & $f$ & & $f$ & & & \\
\hline & & $f$ & & & & $f$ & & & & & & & cus pacificanus \\
\hline & & $f$ & & $\mathrm{f}$ & & & & & & & & & sphaera columella \\
\hline & & & $f$ & r & $r$ & & & & $f$ & $r$ & c & & us crassus \\
\hline & & & & $f$ & & & & $f$ & & & & & olithus nascens \\
\hline & & & & $f$ & $f$ & & $\mathrm{f}$ & & & $r$ & & & ter cf. nodifer \\
\hline & & & & $f$ & $f$ & f & & $f$ & $f$ & $f$ & $f$ & & cccus norrisii \\
\hline & & & & & & $f$ & & & & & & & ter saipanensis \\
\hline & & & & & & $f$ & $r$ & r & $r$ & & & & haera prolixa \\
\hline & & & & & & $f$ & & $f$ & & $f$ & & & ster obscurus \\
\hline & & & & & & & r & & & $f$ & & & s perlongus \\
\hline & & & & & & & $f$ & & $f$ & $f$ & & & fenestra dictyoda \\
\hline & & & & & & & $f$ & & $f$ & $f$ & & & lithus acervus \\
\hline & & & & & & & $f$ & $f$ & $f$ & $f$ & & & olithus nitidus \\
\hline & & & & & & & $f$ & & & & & & ithus ellipticus \\
\hline & & & & & & & & & & $\mathrm{f}$ & & & irba jolotteana \\
\hline
\end{tabular}


TABLE I cont.

\begin{tabular}{|c|c|c|c|c|c|c|c|c|c|c|c|c|c|}
\hline \multicolumn{12}{|c|}{ Cherkessk Fm. } & \multicolumn{2}{|c|}{ Formation } \\
\hline \multicolumn{12}{|c|}{ Unit II } & \multicolumn{2}{|c|}{ Unit } \\
\hline \multicolumn{12}{|c|}{ NP13 } & 1 & \multirow{3}{*}{$\begin{array}{c}\text { Nannofossil } \\
\text { zonations }\end{array}$} \\
\hline \multicolumn{12}{|c|}{ CP11 } & 2 & \\
\hline \multicolumn{12}{|c|}{ CNE5 } & 3 & \\
\hline 30 & 31 & 32 & 33 & 34 & 35 & 36 & 37 & 38 & 39 & 40 & 41 & \multicolumn{2}{|c|}{ Sample nos. } \\
\hline$r$ & $\mathrm{r}$ & $f$ & $f$ & $r$ & $f$ & $\mathrm{f}$ & $\mathrm{f}$ & $r$ & $r$ & $f$ & $r$ & \multicolumn{2}{|c|}{ Blackites perlongus } \\
\hline$f$ & $f$ & $f$ & $f$ & $f$ & & & f & $f$ & $f$ & $f$ & & \multicolumn{2}{|c|}{ Campylosphaera dela } \\
\hline$r$ & $f$ & r & $r$ & $r$ & $r$ & $f$ & $f$ & $r$ & $f$ & $f$ & $r$ & \multicolumn{2}{|c|}{ Chiasmolithus grandis } \\
\hline$f$ & $f$ & $r$ & $r$ & $f$ & & $f$ & & $f$ & $f$ & $f$ & $f$ & \multicolumn{2}{|c|}{ C. nitidus } \\
\hline$f$ & & $r$ & $f$ & & & & & & & & $f$ & \multicolumn{2}{|c|}{ C. solitus } \\
\hline$r$ & $r$ & $r$ & $r$ & $r$ & c & $r$ & $\mathrm{r}$ & $f$ & $r$ & c & $r$ & \multicolumn{2}{|c|}{ Coccolithus formosus } \\
\hline$f$ & $f$ & $f$ & $\mathrm{r}$ & c & c & $r$ & $\mathrm{r}$ & $r$ & c & c & c & \multicolumn{2}{|c|}{ C. pelagicus } \\
\hline$f$ & $f$ & $f$ & $r$ & $\mathrm{r}$ & $r$ & $r$ & & $\mathrm{f}$ & $f$ & $f$ & $r$ & Disc & ster barbadiensis \\
\hline$f$ & $r$ & $f$ & & & $f$ & & $f$ & $r$ & $f$ & $r$ & $f$ & D. $b$ & \\
\hline$f$ & $r$ & $f$ & $r$ & $r$ & $r$ & $r$ & $\mathrm{r}$ & $f$ & & & $r$ & D. $b$ & dosus \\
\hline$r$ & $r$ & $r$ & $r$ & c & c & c & c & $r$ & $f$ & $r$ & $r$ & D. $I$ & ensis \\
\hline$r$ & $r$ & c & c & $r$ & $r$ & $r$ & r & c & $r$ & c & $f$ & Girs & gammation \\
\hline$f$ & $f$ & $f$ & $r$ & $f$ & $r$ & $r$ & $r$ & $r$ & $r$ & $r$ & $f$ & Heli & phaera lophota \\
\hline$r$ & $f$ & $f$ & $f$ & $f$ & & $f$ & $f$ & $r$ & $r$ & $f$ & & H. s & inulum \\
\hline$f$ & & $f$ & & & & & & $\mathrm{f}$ & $f$ & $f$ & & Lop & yolithus nascens \\
\hline$f$ & & $f$ & $f$ & & & $f$ & f & & & & $f$ & Pon & phaera duocava \\
\hline$r$ & $r$ & $r$ & $r$ & $f$ & $f$ & $f$ & $f$ & & & & & P. p & \\
\hline$f$ & & $f$ & $f$ & $f$ & $f$ & & f & f & $f$ & $f$ & & P. p & heroides \\
\hline$f$ & $f$ & $r$ & $f$ & $f$ & & & f & $f$ & $f$ & & & P. p & \\
\hline$f$ & & $f$ & $f$ & $f$ & $f$ & $f$ & f & & $f$ & $f$ & $f$ & Ret & ofenestra dictyoda \\
\hline$r$ & $r$ & $r$ & $r$ & $r$ & $r$ & $f$ & $f$ & & $f$ & $f$ & & & olithus editus \\
\hline$r$ & c & c & a & a & c & c & $r$ & $f$ & $f$ & $f$ & c & S. $r$ & formis \\
\hline$r$ & $f$ & $r$ & c & c & c & $r$ & $\mathrm{r}$ & c & r & c & c & S. $r$ & \\
\hline$f$ & $f$ & $f$ & $r$ & $f$ & $f$ & $f$ & & $r$ & $f$ & $r$ & $f$ & Tov & s magnicrassus \\
\hline$r$ & $r$ & $r$ & $f$ & & & & & & $f$ & $f$ & & T. p & isus \\
\hline$f$ & $f$ & $f$ & $r$ & c & c & c & c & $f$ & & $f$ & a & Zyg & blithus bijugatus \\
\hline & c & c & c & $r$ & $f$ & $f$ & $f$ & c & $f$ & $f$ & c & $\mathrm{Coc}$ & ithus crassus \\
\hline & $f$ & & & $f$ & $f$ & & & $\mathrm{r}$ & $r$ & c & $f$ & Dis & ster deflandrei \\
\hline & $f$ & $f$ & $f$ & $f$ & $f$ & & & & $f$ & & $f$ & D. & operi \\
\hline & $f$ & $f$ & $f$ & & $f$ & $f$ & & & & $f$ & & $\mathrm{Hel}$ & phaera bramlettei \\
\hline & $f$ & $f$ & & & & & & & & & & $\operatorname{Imp}$ & ster obscurus \\
\hline & $f$ & $f$ & & & & & & f & & & $f$ & $\mathrm{NeC}$ & colithes dubius \\
\hline & & $f$ & & & $f$ & & & & $f$ & & & Chi & nolithus expansus \\
\hline & & $f$ & $f$ & $f$ & $f$ & & $\mathrm{f}$ & & & & & $\mathrm{Cla}$ & occus norrisii \\
\hline & & $f$ & $f$ & & $f$ & & & & & & & Dis & ster tanii \\
\hline & & $f$ & $f$ & $f$ & $f$ & & & & $f$ & & & $\mathrm{Nar}$ & urba jolotteana \\
\hline & & $f$ & $f$ & & & $f$ & & f & & & $f$ & Um & osphaera bramlettei \\
\hline & & & $f$ & & & & & & & & & Bla & es gamai \\
\hline & & & $f$ & & & & & & & & & B. $s$ & onii \\
\hline & & & $f$ & & & & & & & & & B. $s$ & osus \\
\hline & & & $f$ & $f$ & $f$ & & & & & & & Chi & nolithus consuetus \\
\hline & & & $f$ & $f$ & $f$ & $f$ & $\mathrm{f}$ & f & $f$ & $f$ & & Cyc & rgolithus floridanus \\
\hline & & & & $f$ & & & & & & & & Scy & sphaera tubicena \\
\hline & & & & $f$ & $f$ & & & & & & & Dis & ster cruciformis \\
\hline & & & & & $f$ & & & & & $f$ & $f$ & D. $\subseteq$ & mifer \\
\hline & & & & & & $\mathrm{f}$ & $\mathrm{f}$ & & & & & Bla & es stilus \\
\hline
\end{tabular}


TABLE II. The dinocyst range chart of Abaza Fm. of the Kheu section (3 parts). Numbers are the counted specimens. Observations after counting are shown as 0

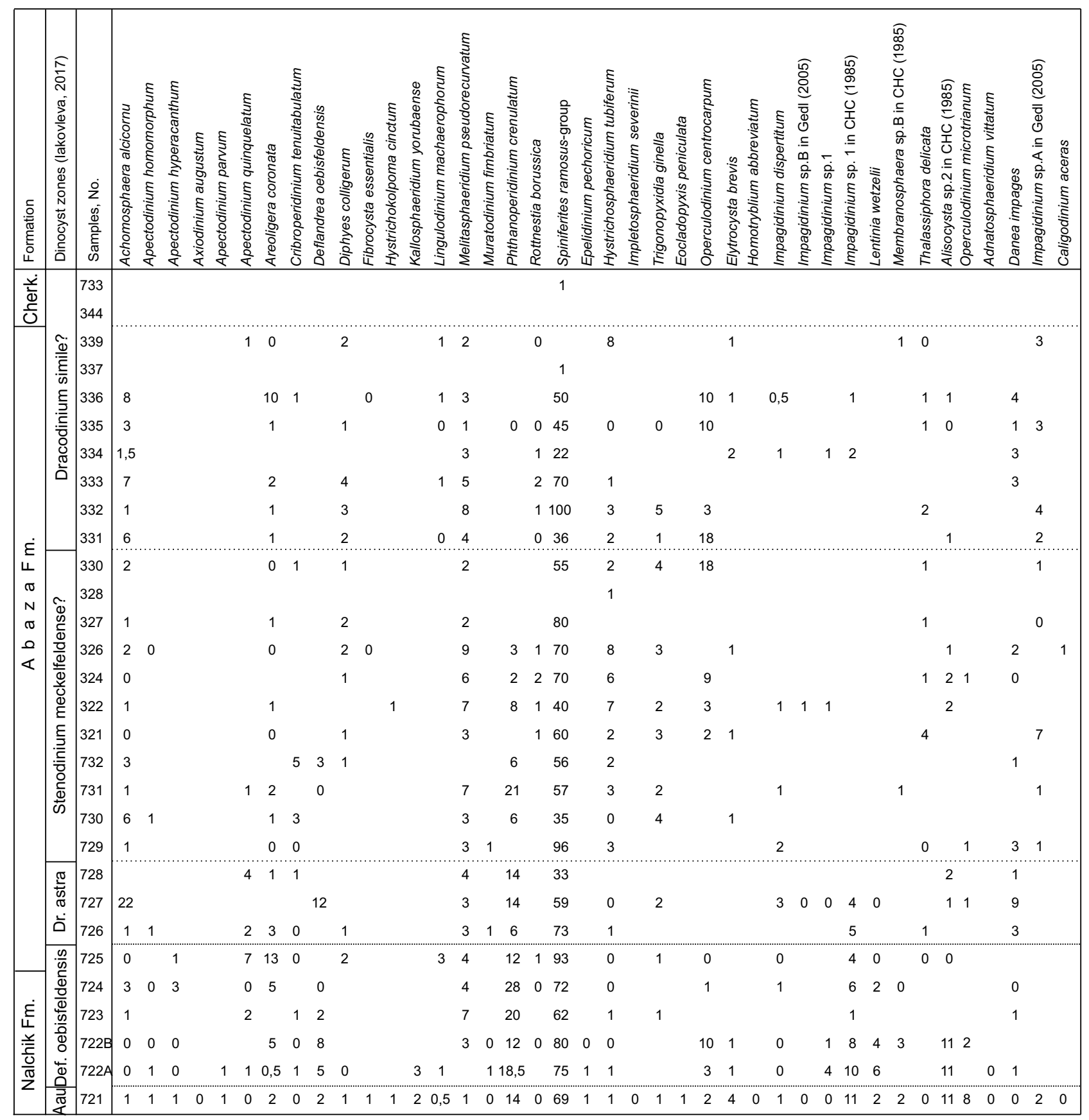


TABLE III. The dinocyst range chart of Cherkessk Fm. of the Kheu section (4 parts). Numbers are the counted specimens. Observations after counting are shown as 0

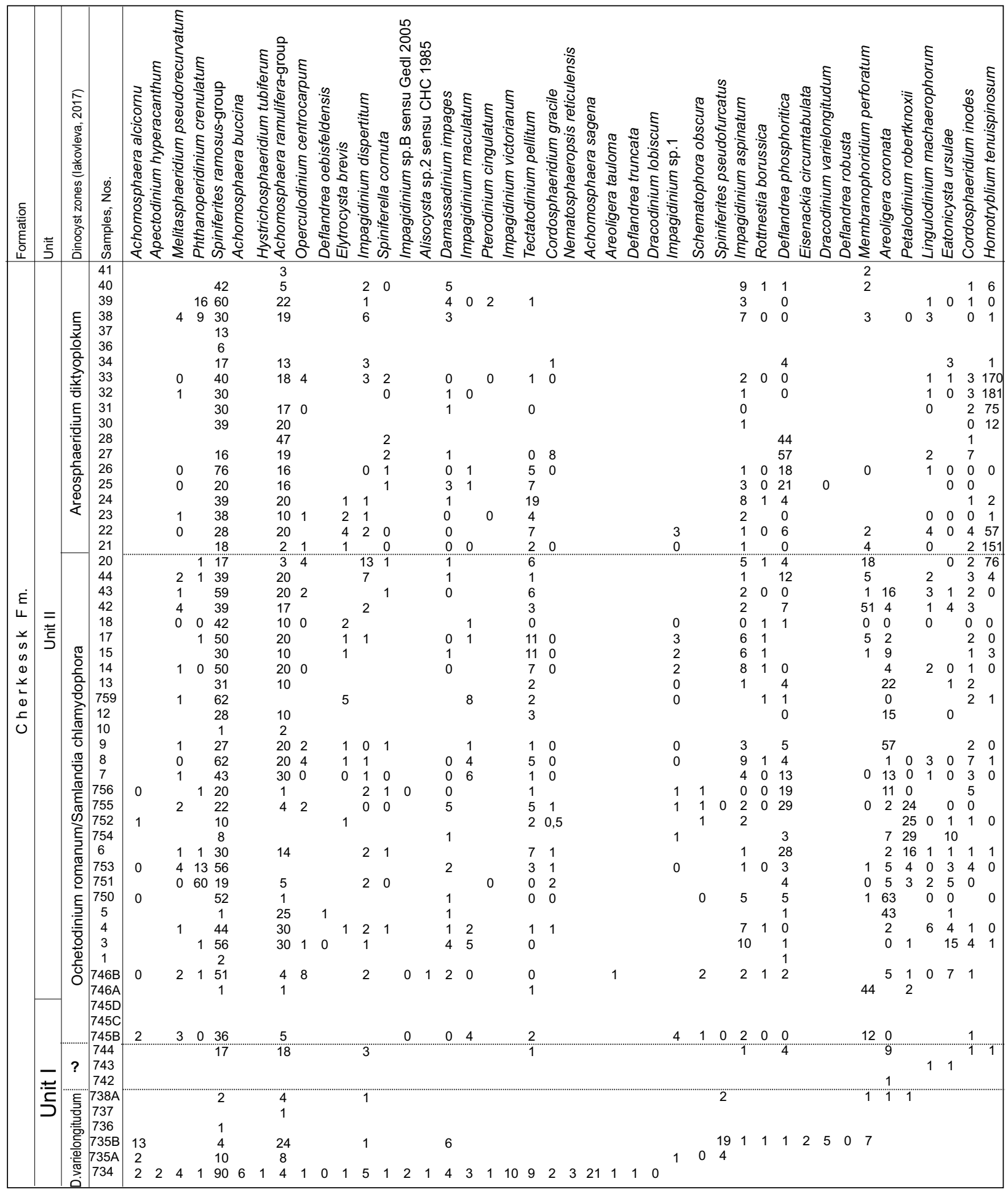




\section{TABLE III cont.}

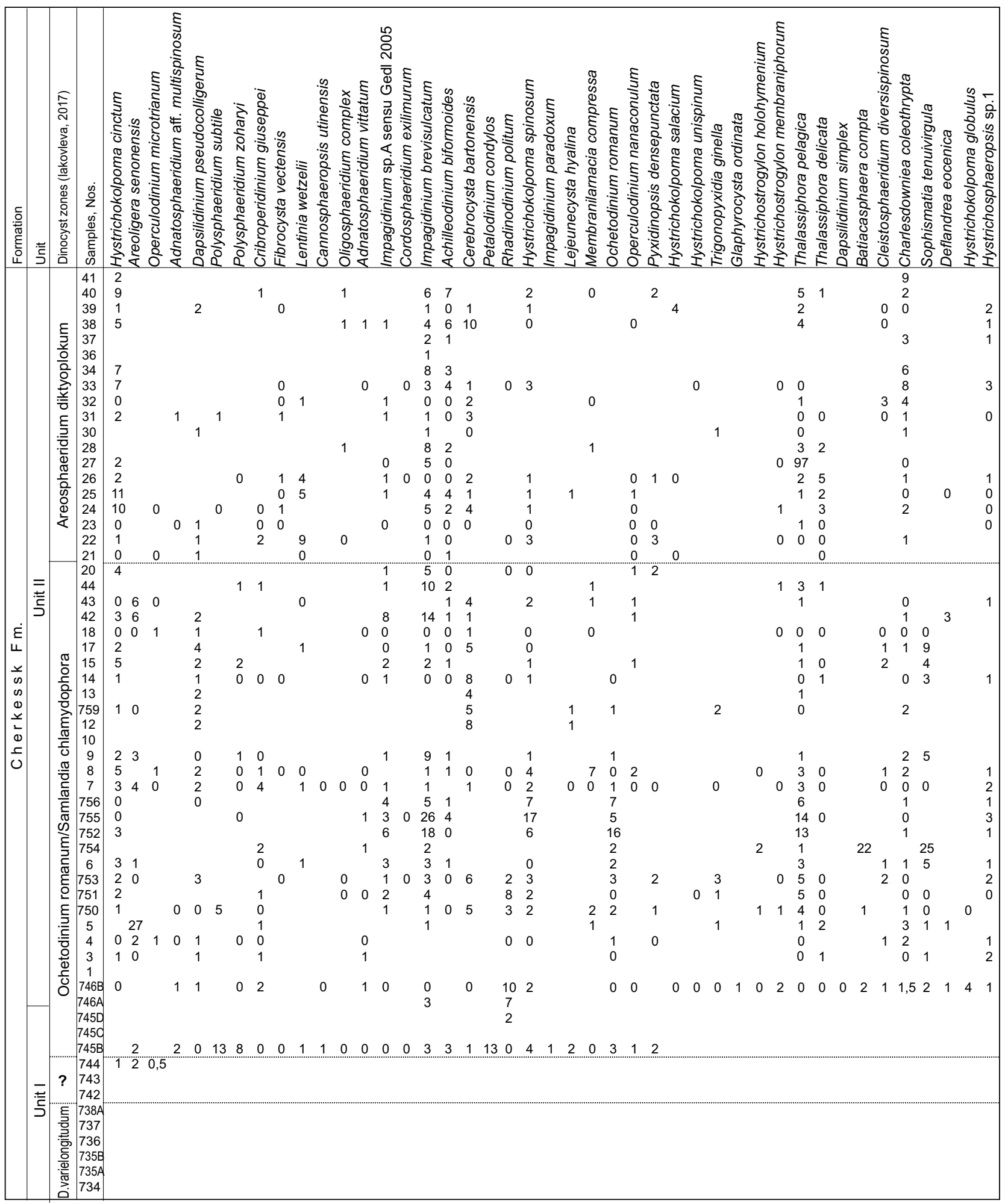


TABLE III cont.

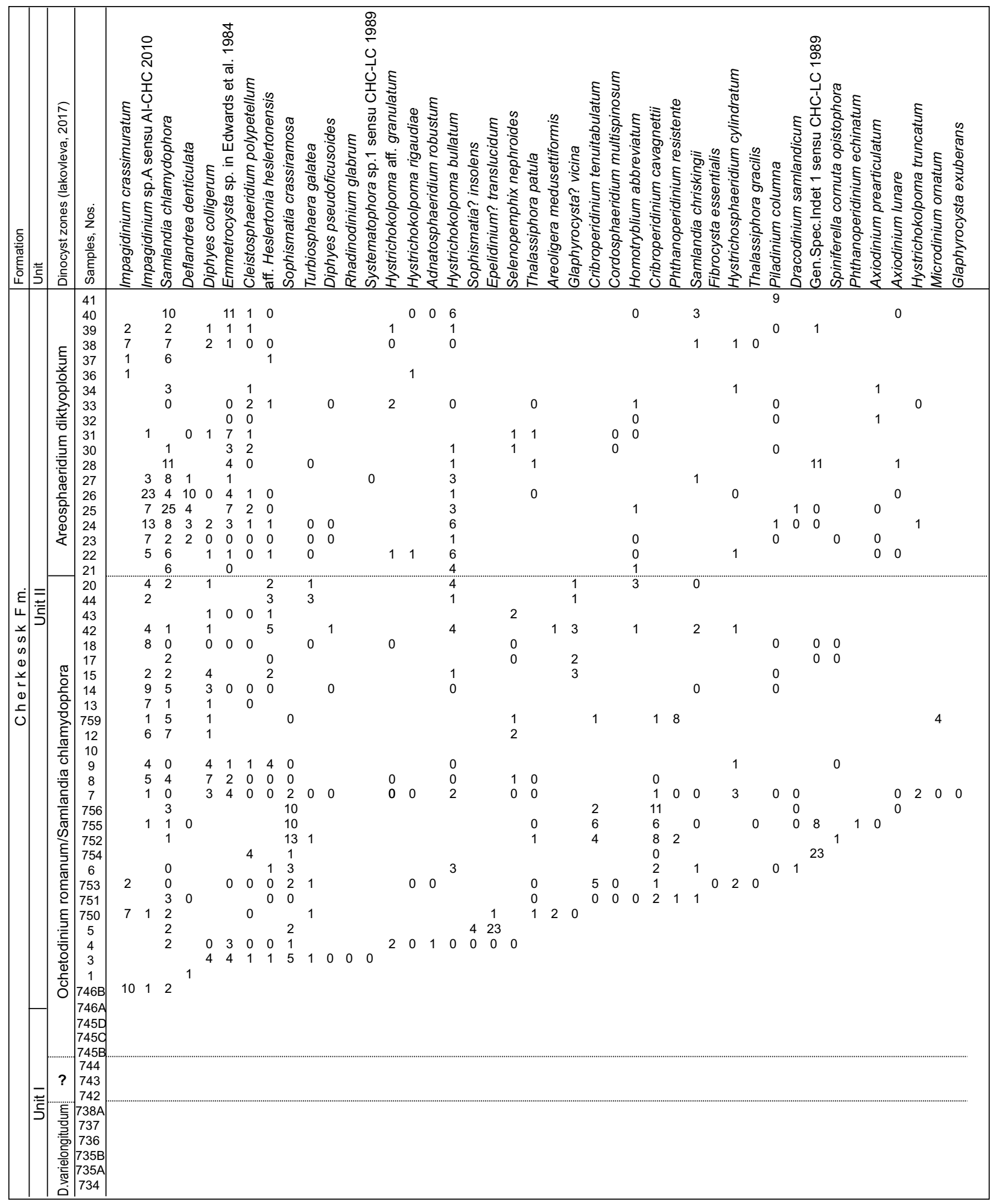




\section{TABLE III cont.}

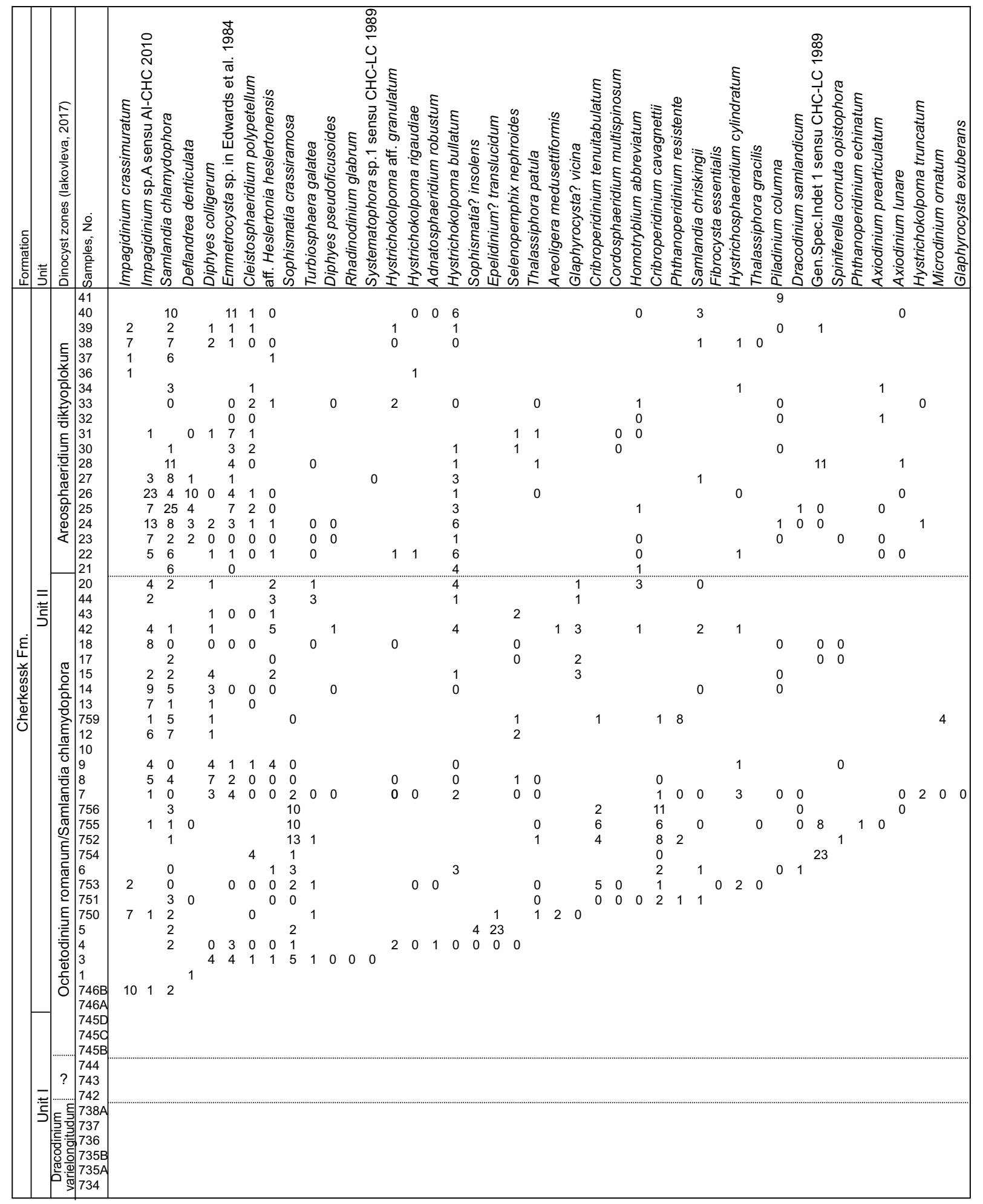


TABLE III cont.

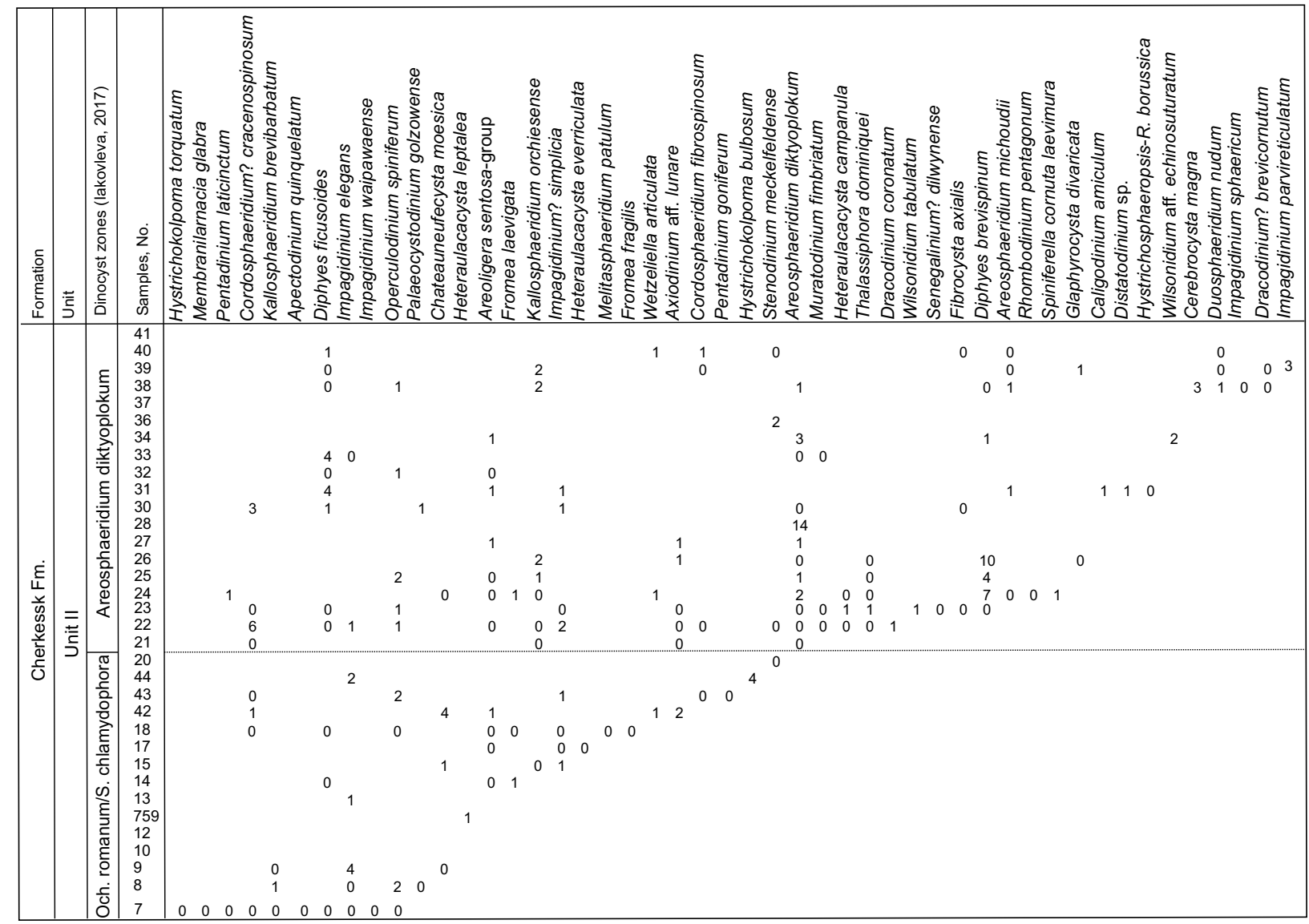



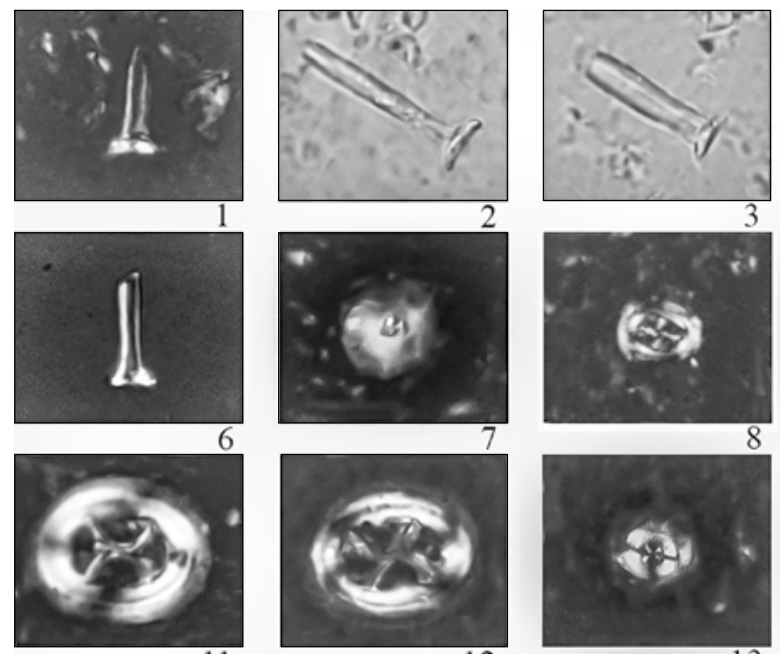

11
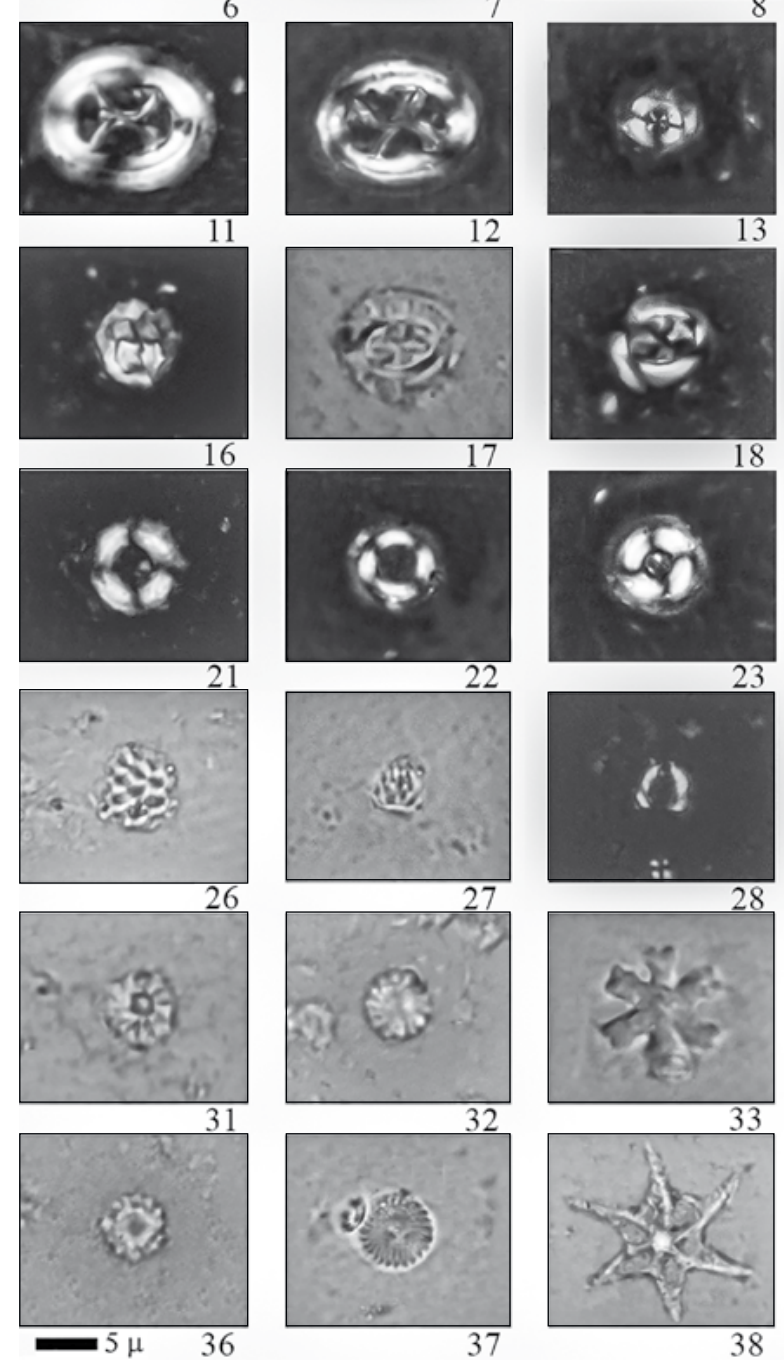

12
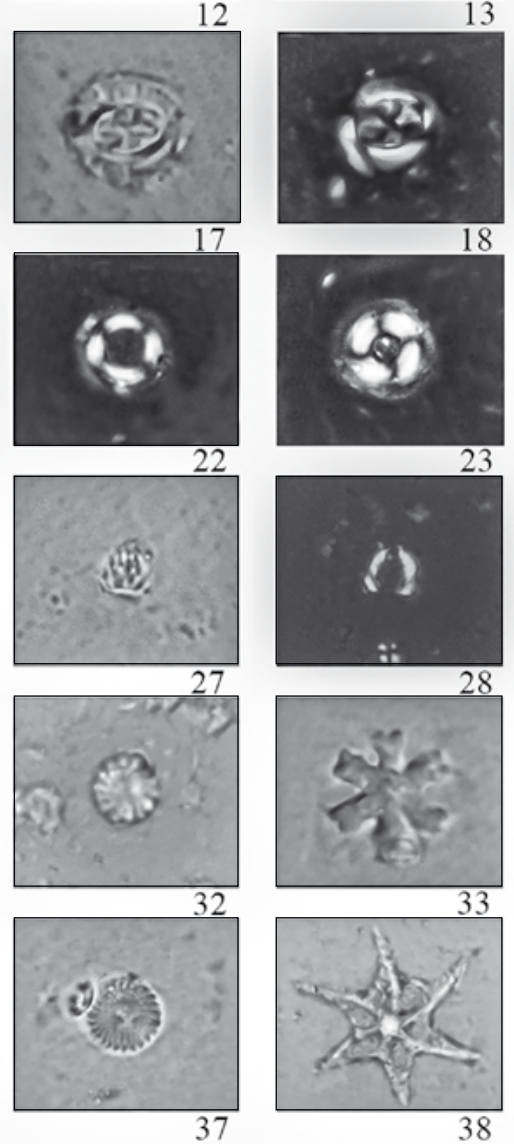
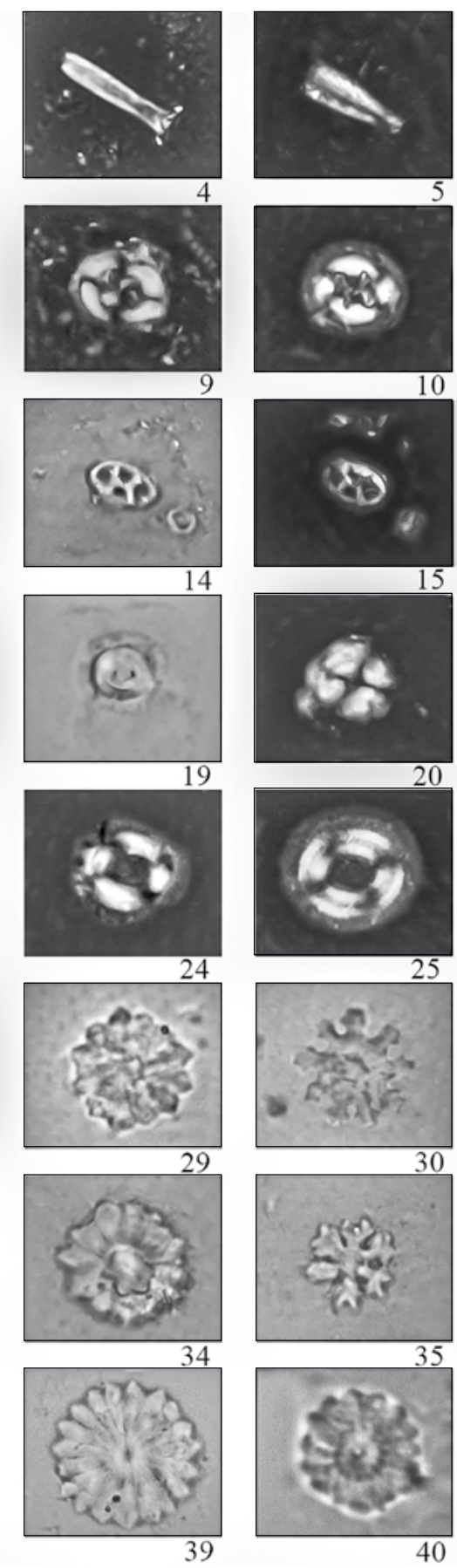

FIGURE I. Light microscope images of Ypresian nannofossils from the Kheu section. XPL: cross-polarized light, IIL: parallel light. 1: Blackites creber (DEFLANDRE, in deflandre and fert) SHERWOOD, sample 746B, CPL; 2: B. perlongus (DEFLANDRE) SHAFIK, sample 7D, IIL; 3, 4, 5: B. solus (PERCH-NIELSEN) BYBELL AND SELF-TRAIL; 3, 4: sample 752 (XPL and IIL, respectively); 5: sample 6, XPL; 6: B. truncatus (BRAMLETTE AND SULLIVAN) VAROL, sample 745D, XPL; 7: Calcidiscus pacificanus (BUKRY) varol, sample 13, XPL; 8: Campylosphaera dela (BRAMLETTE AND SULLIVAN) HAY AND MOHLER, sample 25, XPL; 9: Chiasmolithus bidens (BRAMLETTE AND SULLIVAN) HAY AND MOHLER, sample 740, XP; 10: C. consuetus (BRAMLETTE AND SULLIVAN) HAY AND MOHLER, Sample 757, XP; 11: C. expansus, sample 751, XPL; 12: C. grandis (BRAMLETTE AND RIEDEL) RADOMSKI, sample 3A, XP; 13: C. nitidus PERCH-NIELSEN, sample 738A, XP; 14, 15: Chiphragmalithis armatus PERCH-NIELSEN, sample 9; 14: IIL; 15: XPL; 19, 16: C. calathus BRAMLETTE AND SULLIVAN, sample 438A, XPL; 17, 18: Clausicoccus norrisii BOWN AND NEWSAM, sample 25; 17: IIL; 18: XPL; 19, 20: Coccolithus crassus BRAMLETTE AND SULLIVAN; 19: Sample 20, IIL; 20: sample 27, XPL; 21, 22: C. foraminis Bown; 21: sample 325, XPL; 22: sample 738B, XPL; 23; C. formosus (KAMPTNER) WISE, sample 3A, XPL; 24: C. latus BOWN, sample 335, XPL; 25: C. pelagicus (WALLICH) SCHILLER, sample 757, XPL; 26: Clathrolithus ellipticus DEFLANDRE in deflandre and fert, sample 746A, IIL; 27, 28: Daktylethra probertii BOWN AND DUNKLEY JONES, sample 757; 27: IIL; 28: XPL; 29: Discoaster barbadiensis tan, sample 43, IIL; 30: D. binodosus MARTINI, sample 31, IIL; 31, 32: D. prebifax WEI AND WISE; 31: distal side, sample 13; 32: proximal side, sample 14, IIL; 33: D. deflandrei BRAMLETTE AND RIEDEL, sample 44, IIL; 34: D. diastypus BRAMLETTE AND SULLIVAN, sample 735B, IIL; 35: D. distinctus MARTINI, sample 745D, IIL; 36: D. kuepperi stradNER, sample 13, IIL; 37: D. lenticularis BRAMLETTE AND SULLIVAN, sample 323, IIL; 38: D. Iodoensis BRAMLETTE AND RIEDEL, sample 7D, IIL; 39: D. multiradiatus BRAMLETTE AND RIEDEL, sample 339, IIL; 40: D. salisburgensis STRADNER, sample 327, IIL. 

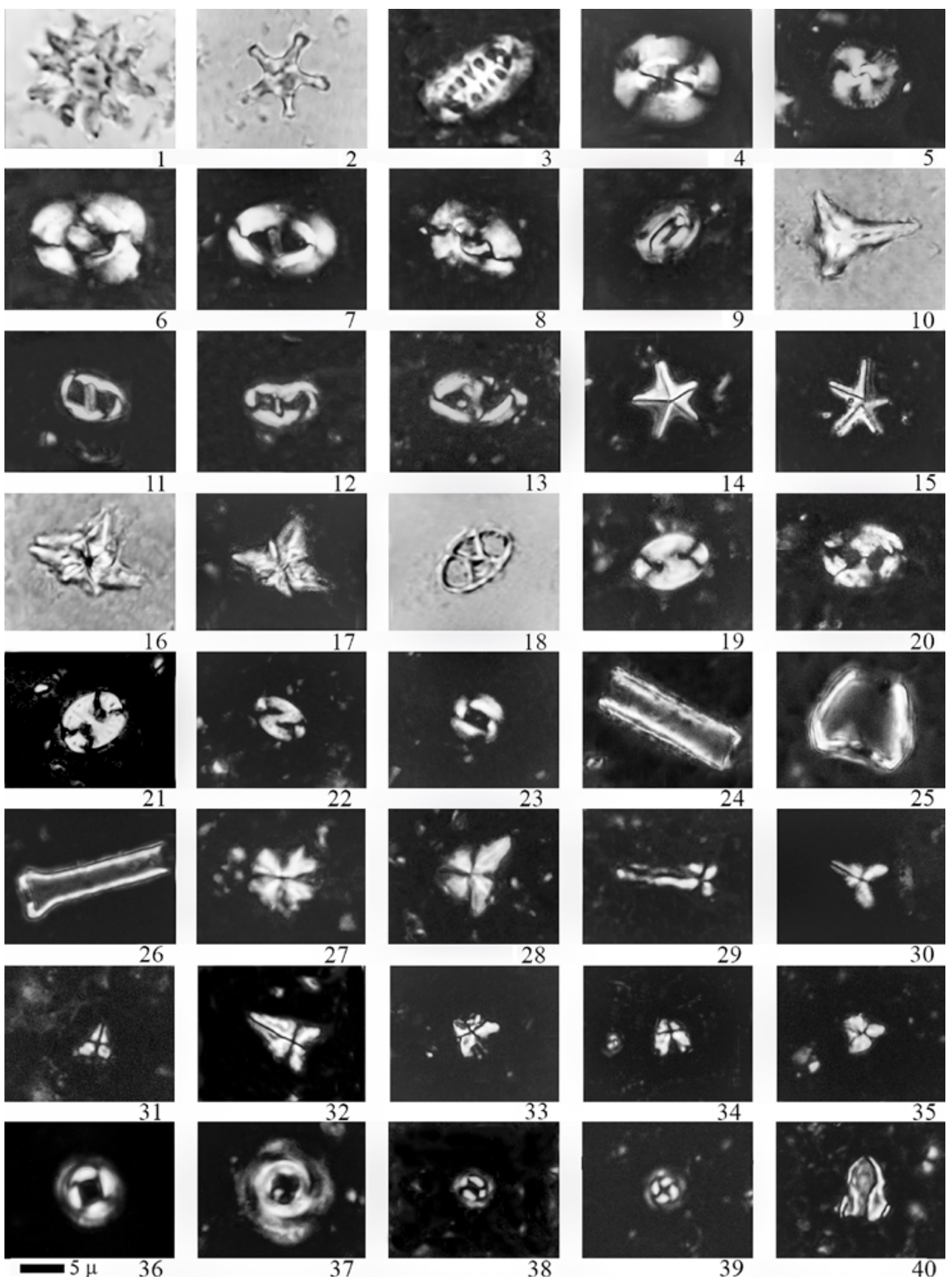

FIGURE II. Light microscope images of Ypresian nannofossils from the Kheu section. XPL: cross-polarized light, IIL: parallel light. 1: Discoaster splendidus MARTINI, sample 724, IIL; 2: Discoaster cf. tanii, sample 43, IIL; 3: Ellipsolithus distichus (BRAMLETTE AND sULLIVAN) SULLIVAN, sample 333, XPL; 4: E. macellus (BRAMLETTE AND SULLIVAN) sULLIVAN, sample 722, XPL; 5: Girgisia gammation (BRAMLETTE AND SULLIVAN) VAROL, sample 26, XPL; 6: Helicosphaera lophota (BRAMLETTE AND SULLIVAN) LOCKER, sample 14, XPL; 7: H. seminulum BRAMLETTE AND SULLIVAN, sample 750, XPL; 8: H. bramlettei (MÜLLER) JAFAR AND MARTINI, sample 33, XPL; 9: Helicosphaera? sp., sample 338, XPL; 10: Imperiaster obscurus (martini) martini, sample 7D, IIL; 11: Lophodolithus nascens BRAMLETTE AND sULLIVAN, sample 745D, XPL; 12: L. reniformis BRAMLETTE AND SULLIVAN, sample 745D, XPL; 13: Lophodolithus sp., sample 745A, XPL; 14: Micrantolithus astrum Bown, sample 750. XPL; 15: M. pinguis BRAMLETTE AND SULLIVAN, sample 3A, XPL; 16, 17: Nannoturba jolotteana STEURBAUT, sample 32; 16: IIL; 17: XPL; 18: Neococcolithes protenus (BRAMLETTE AND SULLIVAN) BLACK, sample 39, IIL; 19: Pontosphaera duocava (BRAmLETTE AND sulLIVAN) RomeIn, sample 13, XPL; 20: P. exilis (BRAMLETTE AND SULLIVAN) ROMEIN, sample 324, XPL; 21: P. pulchra (DEFLANDRE in deflandre and fert) ROMEIN, sample 746A, XPL; 22: P. pulcheroides (sULLIVAN, 1964) ROMEIN, sample 25, XPL; 23: Reticulofenestra dictyoda (DEFLANDRE in deflandre and fert) STRADNER; 24: Scyphosphaera columella STRADNER, sample 4, XPL; 25: S. tersiensis LEZAUD, sample 3B, XPL; 26: S. tubicena STRADNER, sample 757, XPL; 27: Sphenolithus acervus Bown, sample 21, XPL; 28: S. arthurii Bown, sample 32, XPL; 29: S. conspiquUS MARTINI, sample 38, XPL; 30: S. editus PERCH-NIELSEN, sample 43 XPL; 31: S. orphanknollensis PERCH-NIELSEN, sample 435B, XPL; 32: S. radians DEFLANDRE IN GRASSÉ, sample 17, XPL; 33: Sphenolithus cf. bipedis BERGEN AND DE KAENEL, sample 735B, XPL; 34: Sphenolithus cf. bipedis BERGEN AND DE KAENEL, sample 738A, XPL; 35: Sphenolithus sp., sample 738A, XPL; 36: Toweius callosuS PERCH-NIELSEN, sample 327, XPL; 37: T. magnicrassus (BUKRY) ROMEIN, sample 25, XPL; 38: T. pertusus (sULLIVAN) ROMEIN, sample 337, XPL; 39: T. rotundus PERCHNIELSEN, sample 337, XPL; 40: Zygrhablithus bijugatus galeiformis STEURBAUT, sample 745A, XPL. 

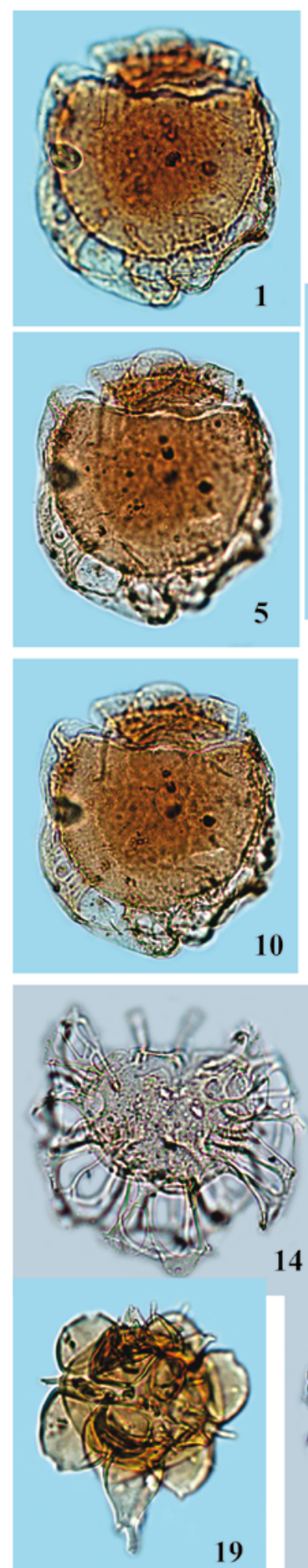
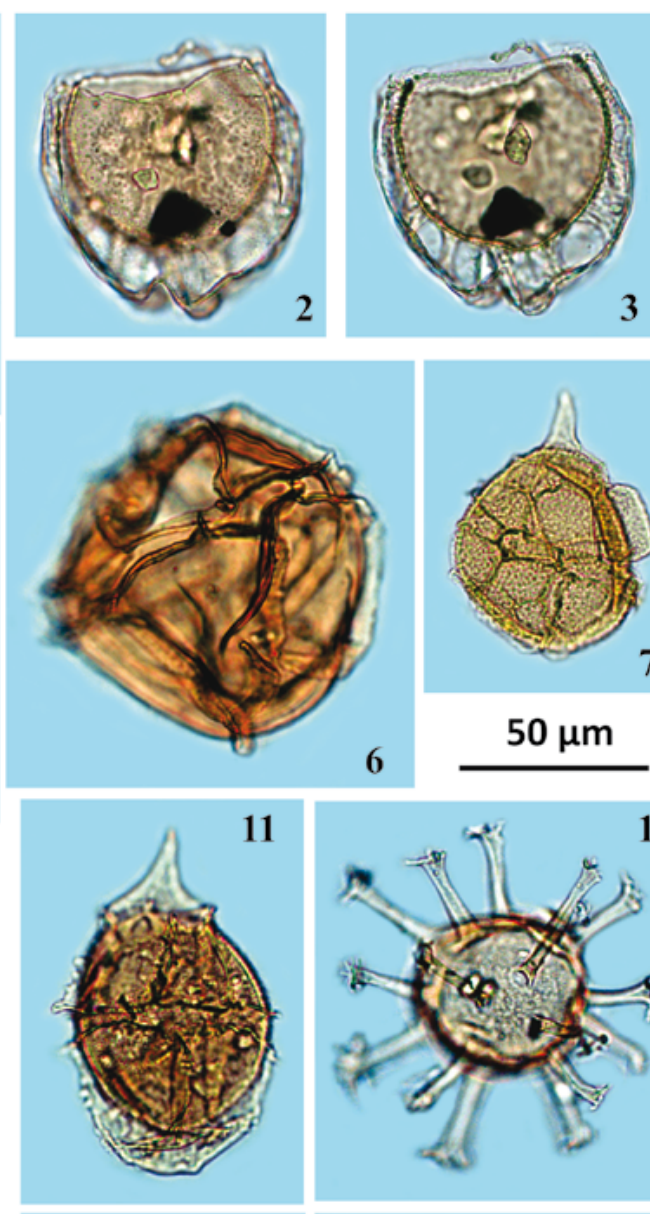

15
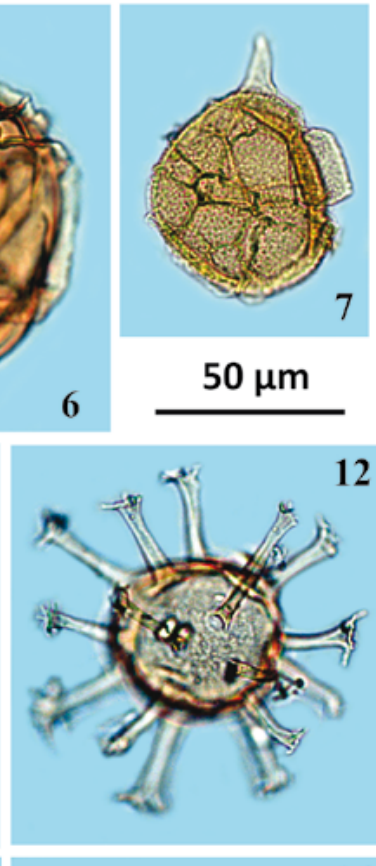

(1)
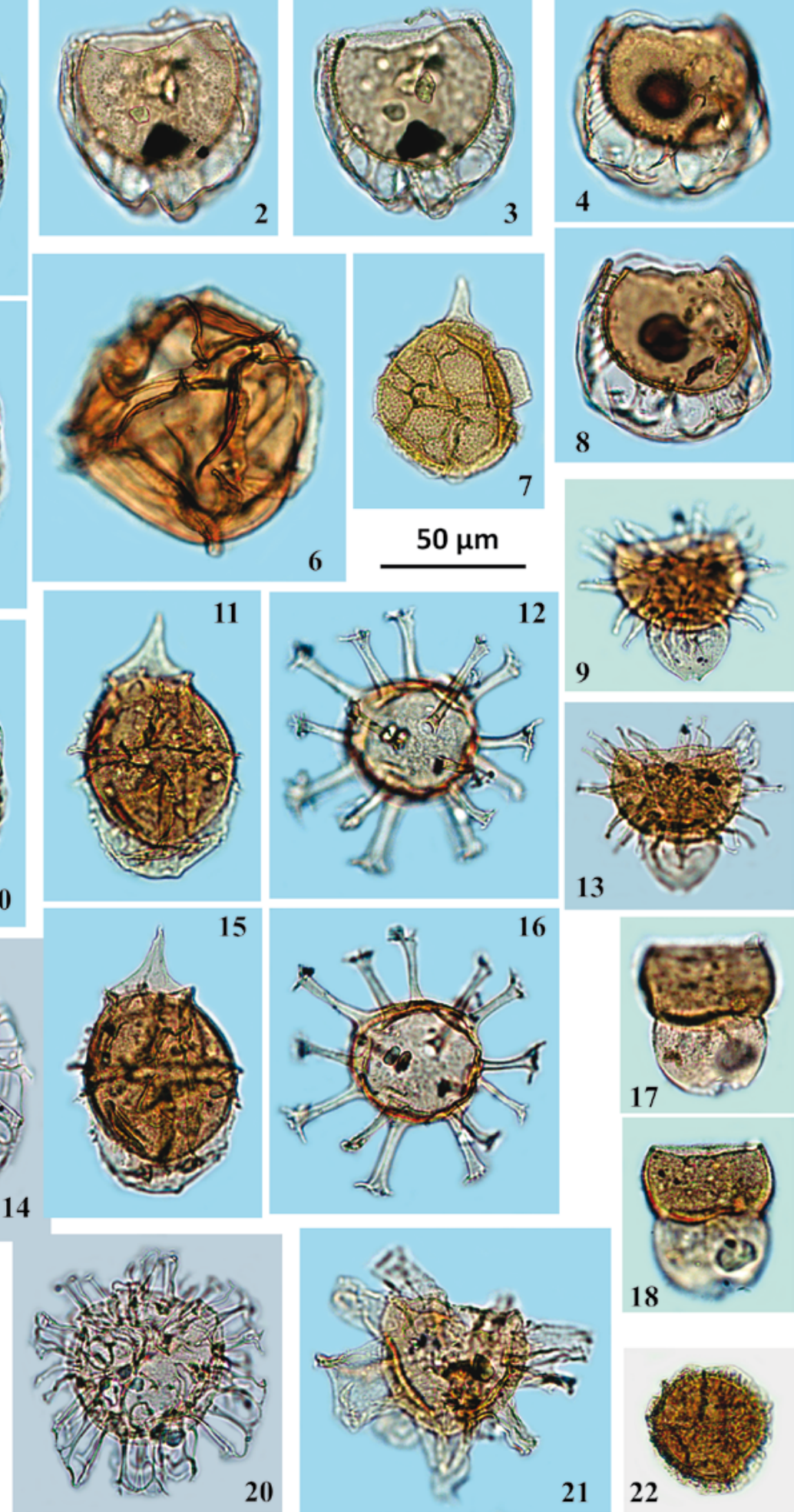

FIGURE III. Light microscope images of Ypresian dinocysts from the Kheu section. 1, 5, 10: Membranophoridium perforatum gerlach, sample 18D (slide 18D-1); 2-3: Membranophoridium perforatum, sample 20 (slide 20-2); 4, 8: Membranophoridium perforatum, sample 17 (slide 17-1); 6: Impagidinium brevisulcatum MICHOUX, sample 33 (slide 33-1); 7: Impagidinium aspinatum (COOKSON AND EISENACK) DAMASSA, sample 22 (slide 22-2); 9, 13: Diphyes ficusoides islam, sample 33 (slide 33-1); 11, 15: Hystrichosphaeropsis sp.1, sample 22 (slide 22-2); 12, 16: Homotryblium tenuispinosum DAvEY ET WILLIAMS, sample 33 (slide 33-1); 14: Emmetrocysta sp. in EDWARDS ET AL., 1983, sample 7B (slide 7B-2); 17-18: Duosphaeridium nudum (cookson) LOEBLICH AND LOEBLICH, sample 39 (slide 39-1); 19: Hystrichokolpoma cinctum KLUMPP, sample 33 (slide 33-1); 20: Cleistosphaeridium polypetellum (DAVEY ET AL.) ISLAM, sample 22 (slide 22-2); 21: Hystrichokolpoma unispinum WILlIAMS AND DOWNIE, sample 20 (slide 20-2); 21: Ochetodinium romanum DAMASSA, sample 746B (slide 746B-1). 

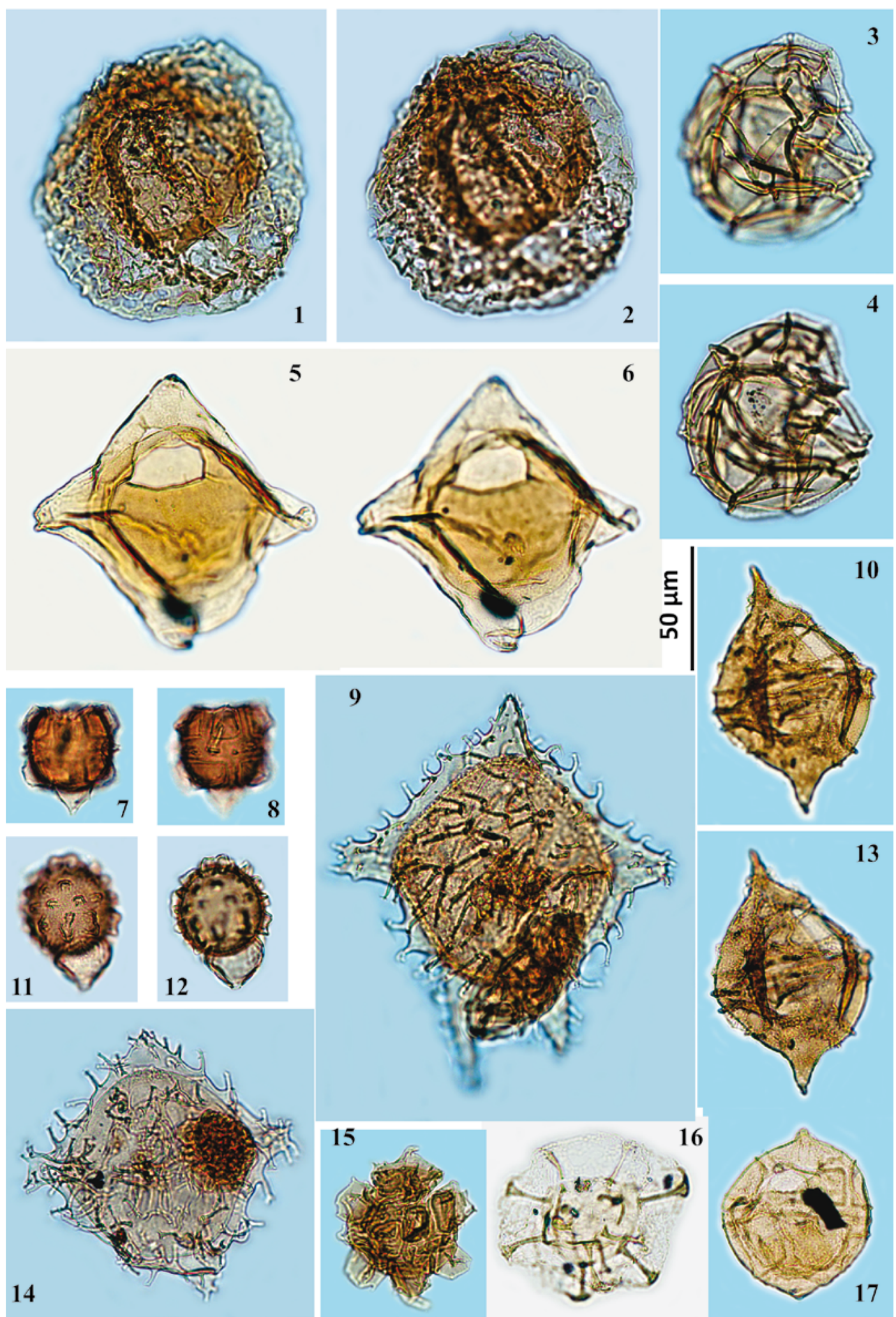

11

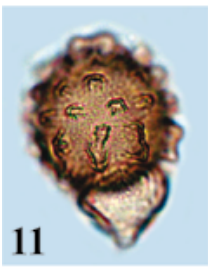

12
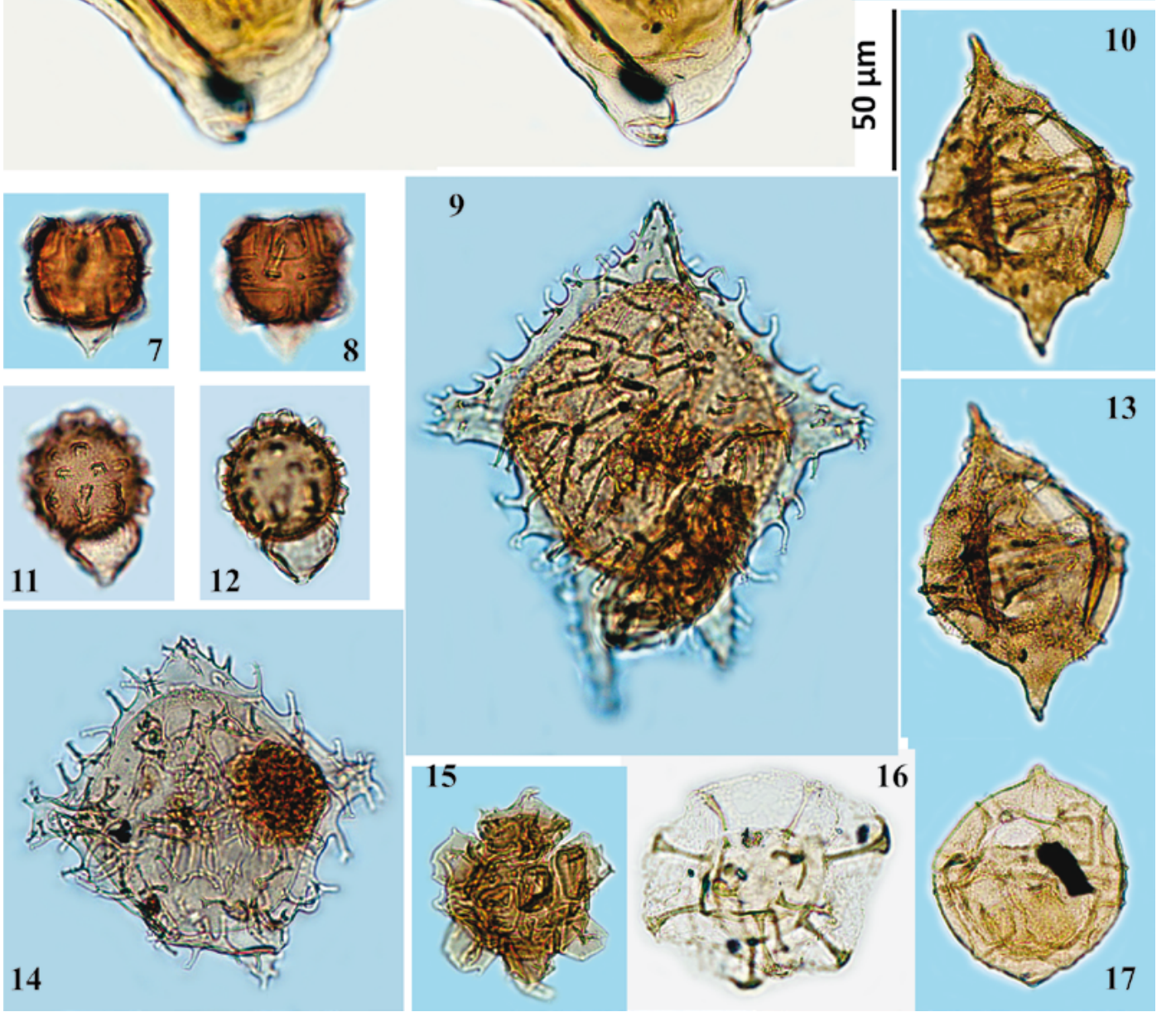

FIGURE IV. Light microscope images of Ypresian dinocysts from the Kheu section. 1-2: Thalassiphora dominiquei IAKOVLEVA AND HEILMANN-CLAUSEN, sample 25 (slide 25-1); 3, 4: Impagidinium brevisulcatum, sample 26 (slide 26-2); 5-6: Rhadinodinium politum (BUJAK ET AL.) WILLIAMS ET AL., sample 745B (slide 745B-1); 7-8: Hystrichokolpoma truncatum BIFFI AND MANUM, sample 7A (slide 7A-1); 9: Axiodinium prearticulatum FENSOME ET AL., sample 38 (slide 38-1); 10, 13: Damassadinium impages (DAMASSA) FENSOME ET AL., sample 735B (slide 735B-1); 11-12: Diphyes brevispinum, sample 24B (slide 24B-1); 14: Axiodinium prearticulatum fensome et al., sample 22 (slide 22-2); 15: Hystrichokolpoma spinosum wILSON, sample 40A (slide 40A1); 16: Eatonicysta ursulae (MORGENROTH) STOVER AND EVITT, sample 746B (slide 746B-1); 17: Damassadinium impages, sample 750 (slide $750-1$ ). 

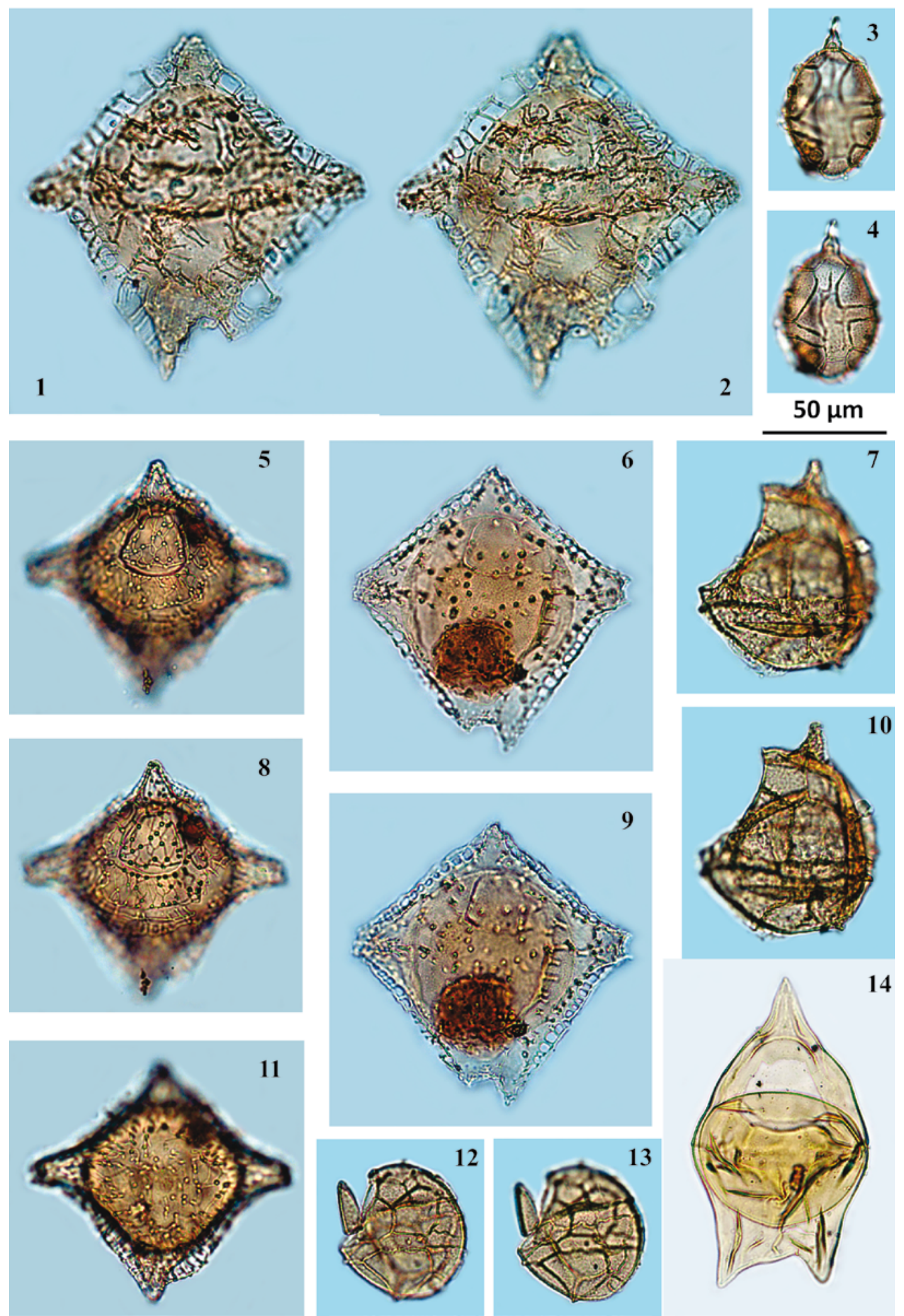

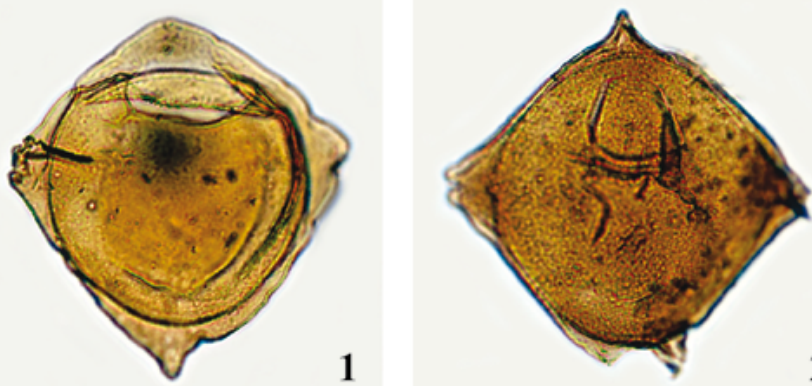

2
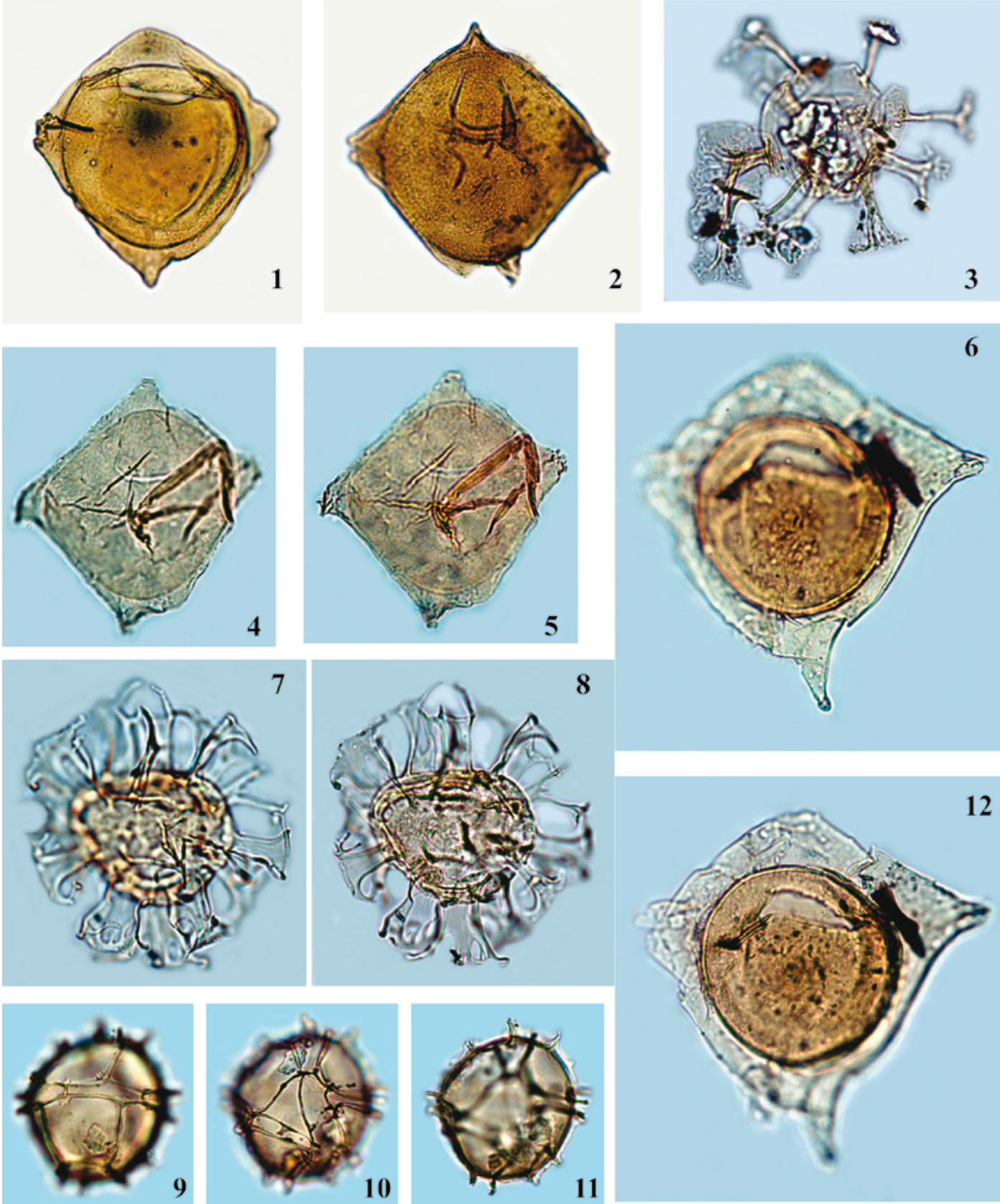

8
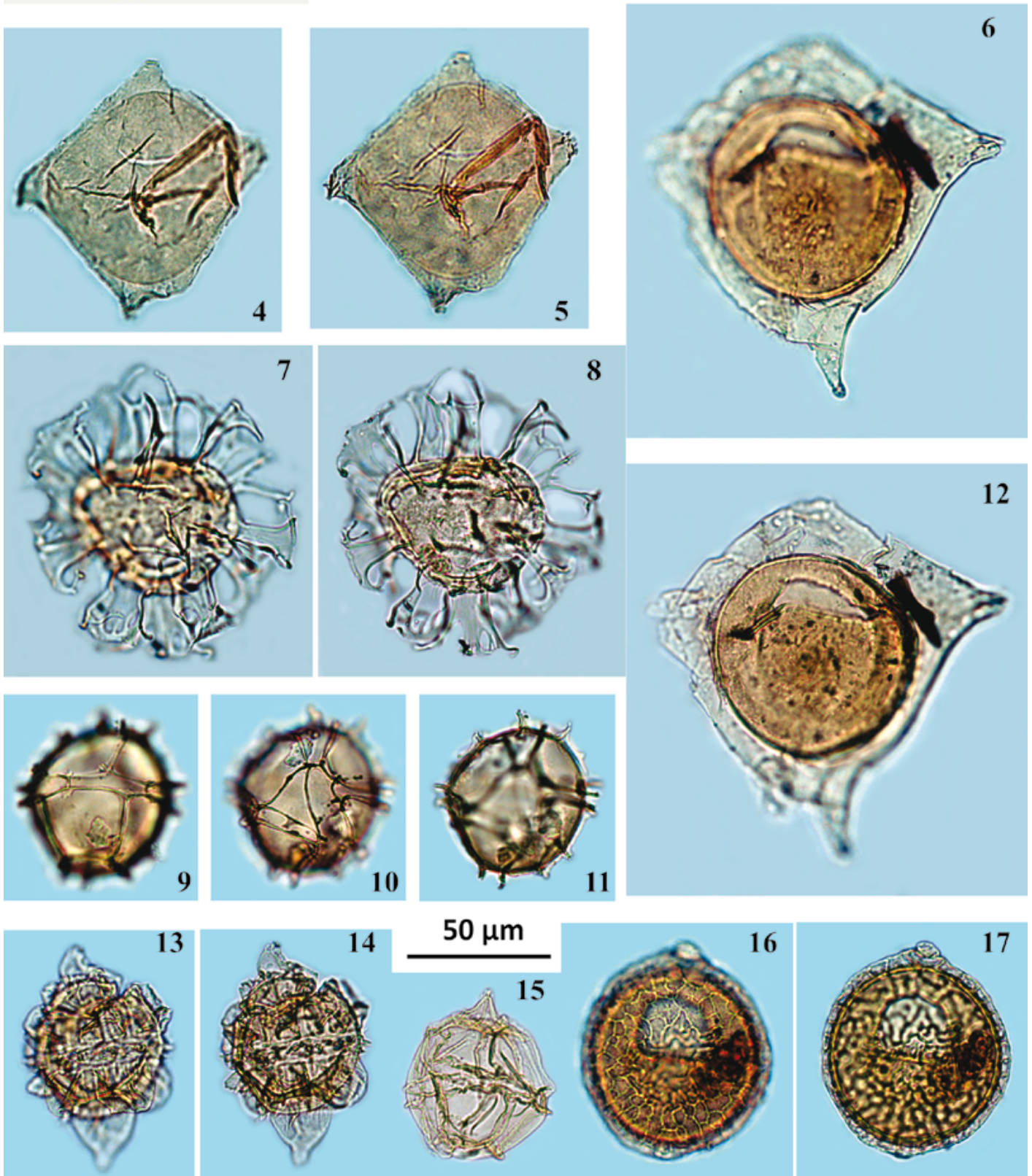

12
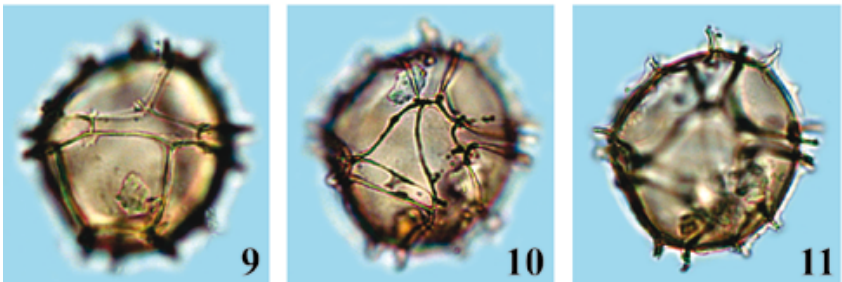

\section{1}
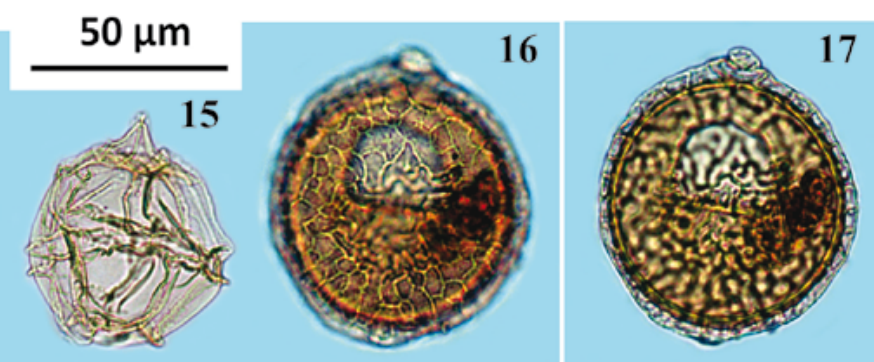

FIGURE VI. Light microscope images of Ypresian dinocysts from the Kheu section. 1: Dracodinium sp.1 sensu IAKOVLEVA AND HEILMANN-CLAUSEN, sample 746B (slide 746B-1); 2: Wilsonidium tabulatum (WILSON) LENTIN AND WILLIAMS, sample 745B (slide 745B-1); 3: Areosphaeridium diktyoplokum (KLUMPP) EATON, sample 38 (slide 38-1); 4-5: Epelidinium? translucidum (MICHOUX) WILLIAMS ET AL., sample 5 (slide 5-1); 6, 12: Rhadinodinium politum (BUJAK ET AL.) WILLIAMS ET AL.., sample 3B (slide 3B-1); 7-8: Areoligera sentosa-group sensu IAKOVLEVA AND HEILMANN-CLAUSEN, sample 14 (slide 14-1); 9-11: Impagidinium sphaericum (WALL) LENTIN AND WILLIAMS, sample 38 (slide 38-1); 13-14: Hystrichokolpoma sp. in wILson, 1988, sample 7B (slide 7B-2); 15: Impagidinium sp.1, sample 20 (slide 20-2); 16-17: Samlandia chlamydophora EISENACK, sample 26 (slide 26-2). 